\title{
Probing the role of the divalent metal ion in uteroferrin using metal ion replacement and a comparison to isostructural biomimetics
}

\author{
Gerhard Schenk $\cdot$ Rosely A. Peralta $\cdot$ Suzana Cimara Batista $\cdot$ Adailton J. Bortoluzzi $\cdot$ \\ Bruno Szpoganicz • Andrew K. Dick · Paul Herrald · Graeme R. Hanson · \\ Robert K. Szilagyi · Mark J. Riley · Lawrence R. Gahan · Ademir Neves
}

Received: 5 August 2007/ Accepted: 28 September 2007/Published online: 16 October 2007

(C) SBIC 2007

\begin{abstract}
Purple acid phosphatases (PAPs) are a group of heterovalent binuclear metalloenzymes that catalyze the hydrolysis of phosphomonoesters at acidic to neutral $\mathrm{pH}$. While the metal ions are essential for catalysis, their precise roles are not fully understood. Here, the Fe(III)Ni(II) derivative of pig PAP (uteroferrin) was generated and its properties were compared with those of the native $\mathrm{Fe}(\mathrm{III}) \mathrm{Fe}(\mathrm{II})$ enzyme. The $k_{\text {cat }}$ of the $\mathrm{Fe}(\mathrm{III}) \mathrm{Ni}(\mathrm{II})$ derivative (approximately $60 \mathrm{~s}^{-1}$ ) is approximately $20 \%$ of that of native uteroferrin, and the $\mathrm{Ni}(\mathrm{II})$ uptake is considerably faster than the reconstitution of full enzymatic activity, suggesting a slow conformational change is required to
\end{abstract}

Electronic supplementary material The online version of this article (doi:10.1007/s00775-007-0305-z) contains supplementary material, which is available to authorized users.

G. Schenk $(\bowtie) \cdot$ A. K. Dick · P. Herrald .

M. J. Riley · L. R. Gahan

School of Molecular and Microbial Sciences,

The University of Queensland,

St Lucia, QLD 4072, Australia

e-mail: schenk@uq.edu.au

R. A. Peralta $\cdot$ S. C. Batista $\cdot$ A. J. Bortoluzzi $\cdot$

B. Szpoganicz $\cdot$ A. Neves $(\bowtie)$

Departamento de Química,

Universidade Federal de Santa Catarina,

Florianópolis, SC 88040-900, Brazil

e-mail: ademir@qmc.ufsc.br

G. R. Hanson

Centre for Magnetic Resonance,

The University of Queensland,

St Lucia, QLD 4072, Australia

R. K. Szilagyi

Department of Chemistry and Biochemistry,

Montana State University,

Bozeman, MT 59717-3400, USA attain optimal reactivity. An analysis of the $\mathrm{pH}$ dependence of the catalytic properties of $\mathrm{Fe}(\mathrm{III}) \mathrm{Ni}(\mathrm{II})$ uteroferrin indicates that the $\mu$-hydroxide is the likely nucleophile. Thus, the $\mathrm{Ni}(\mathrm{II})$ derivative employs a mechanism similar to that proposed for the $\mathrm{Ga}(\mathrm{III}) \mathrm{Zn}$ (II) derivative of uteroferrin, but different from that of the native enzyme, which uses a terminal $\mathrm{Fe}$ (III)-bound nucleophile to initiate catalysis. Binuclear $\mathrm{Fe}(\mathrm{III}) \mathrm{Ni}(\mathrm{II})$ biomimetics with coordination environments similar to the coordination environment of uteroferrin were generated to provide both experimental benchmarks (structural and spectroscopic) and further insight into the catalytic mechanism of hydrolysis. The data are consistent with a reaction mechanism employing an $\mathrm{Fe}(\mathrm{III})$-bound terminal hydroxide as a nucleophile, similar to that proposed for native uteroferrin and various related isostructural biomimetics. Thus, only in the uteroferrin-catalyzed reaction are the precise details of the catalytic mechanism sensitive to the metal ion composition, illustrating the significance of the dynamic ligand environment in the protein active site for the optimization of the catalytic efficiency.

Keywords Binuclear metallohydrolases . Purple acid phosphatases - Uteroferrin - Catalysis .

Metal ion replacement

\section{Introduction}

Purple acid phosphatases (PAPs) belong to the family of binuclear metallohydrolases, a large group of enzymes involved in a range of metabolic functions [1,2]. Members of this family have emerged as promising candidates for the development of drugs and bioremediation agents. PAPs catalyze the hydrolysis of a broad range of phosphorylated 
substrates at acidic to neutral $\mathrm{pH}$, and they require a heterovalent bimetallic active site for reactivity $[1,2]$. PAPs isolated from mammalian organisms are approximately $35 \mathrm{kDa}$ monomers with a redox-active $\mathrm{Fe}(\mathrm{III}) \mathrm{Fe}(\mathrm{II} / \mathrm{III})$ center and a highly conserved amino acid sequence with at least $85 \%$ identity across species [1-5]. Homodimeric plant PAPs, extracted from red kidney bean, soybean and sweet potato [6-8], have a subunit molecular mass of approximately $55 \mathrm{kDa}$, and the amino acid sequences are homologous, sharing at least $65 \%$ identity [5, 7]. The metal ion composition in plant PAPs is either $\mathrm{Fe}(\mathrm{III}) \mathrm{Zn}$ (II) or $\mathrm{Fe}(\mathrm{III}) \mathrm{Mn}$ (II) [6-9]. Common to all PAPs is the characteristic purple color, which is due to a charge transfer transition $\left(\lambda_{\max }=510-560 \mathrm{~nm} ; \varepsilon \sim 3,000-4,000 \mathrm{M}^{-1} \mathrm{~cm}^{-1}\right)$ in the active site from a conserved tyrosine ligand to the ferric ion [10-12].

The metal ions in the active sites of PAPs are coordinated by seven invariant amino acid side chains (Fig. 1). Apart from the chromophoric tyrosine ligand the Fe(III) is coordinated to the nitrogen atom of a histidine and the oxygen atoms of two aspartate residues, one of which bridges the two metal ions. The divalent metal ion is coordinated to the oxygen atom of the bridging aspartate, the nitrogen atoms of two histidine residues and an asparagine oxygen atom. On the basis of recent spectroscopic and crystallographic data, the Fe(III) in the resting state is five-coordinate, including a bridging (hydr)oxo ligand; the $\mathrm{M}(\mathrm{II})$ site is likely to be six-coordinate with a terminal water molecule completing its first coordination sphere [13]. The enzyme thus provides an asymmetric binuclear active site with an $\mathrm{NO}_{4} \mathrm{Fe}(\mathrm{III})$ site and an $\mathrm{N}_{2} \mathrm{O}_{4}$ divalent metal site (Fig. 1).

All PAPs are believed to employ variants of a similar basic mechanism to catalyze the hydrolysis of monophosphate ester bonds [1, 2, 14]. In the proposed models for catalysis, the identity of the attacking nucleophile, the structure of the transition state and the relative contribution of the metal ions to PAP reactivity all vary. This reflects the differences in metal ion composition, the protonation

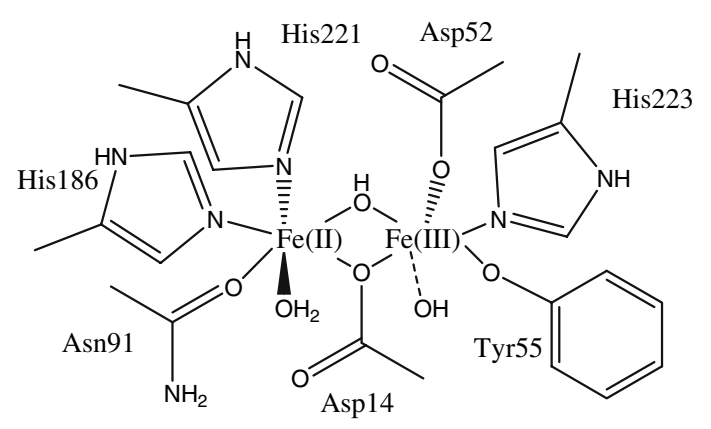

Fig. 1 The active site of purple acid phosphatases (PAPs). Residue labels refer to the sequence of pig PAP (uteroferrin, Uf) state of metal-bound water molecules and structural variations in the immediate vicinity of the binuclear metal center. A recent study has shown that PAPs are likely to employ a flexible mechanistic strategy ("one enzyme-two mechanisms") whereby the metal ion composition, the second coordination sphere and the substrate itself affect the catalytic mechanism [15]. It could be demonstrated that native di-iron pig PAP (uteroferrin, Uf) hydrolyzes both ester bonds of a diester substrate in a sequential manner, indicating that two nucleophiles are operational in this enzyme, one terminally bound to the trivalent metal ion, the other one bridging the irons [16]. Furthermore, the replacement of the $\mathrm{Fe}$ (III) by $\mathrm{Ga}$ (III) leads to a change in the identity of the reaction-initiating nucleophile for the hydrolysis of the monoester substrate para-nitrophenyl phosphate (pNPP), from the terminal to the bridging hydroxide [15]. Thus, the Ga(III) derivative of Uf employs a mechanism similar to that proposed for the $\mathrm{Fe}(\mathrm{III}) \mathrm{Mn}$ (II) sweet potato PAP (Scheme 1) [9, 14]. No crystallographic data that may provide insight into structural changes that occur owing to the metal ion replacements in Uf are currently available. However, with fluoride as an inhibitory probe, it has recently been shown that the active-site structure of Uf is likely to represent an equilibrium between a conformation susceptible to fluoride and one that is not, an observation that suggests some structural flexibility [17]. This flexibility may be associated with an exposed loop close to the active site; proteolytic cleavage within this loop has been shown to alter both reactivity and substrate specificity $[18,19]$.

From the above discussion it follows that replacement of the trivalent metal ion in Uf may alter the molecular mechanism of catalysis by possibly inducing subtle structural changes in the active site. In contrast, in the best characterized derivative of Uf, where the Fe(II) has been exchanged by $\mathrm{Zn}(\mathrm{II})$, the metal ion replacement does not appear to affect the catalytic properties of the enzyme significantly [15]. While this may indicate that the divalent metal binding site is less susceptible to structural changes, it should also be noted that other divalent metal ions (e.g., $\mathrm{Cu}(\mathrm{II}), \mathrm{Co}(\mathrm{II}), \mathrm{Mn}(\mathrm{II})$ and $\mathrm{Hg}(\mathrm{II})$ [20, 21]) induce more significant catalytic changes. A similar observation was reported for the PAP from red kidney bean, where the substitution of the native $\mathrm{Zn}$ (II) by Fe(II) does not lead to significant changes in catalytic performance [22], but other derivatives are considerably less reactive [23]. Here, we decided to probe the role of the divalent metal ion in Uf by replacing the native iron by $\mathrm{Ni}$ (II) and monitoring the catalytic effects caused by this substitution. Of interest is the effect of this substitution on $\mathrm{p} K_{\mathrm{a}}$ values associated with the hydrolytic reaction since a comparison between the native enzyme and the derivatives may aid in the identification of ligands and residues important in catalysis. 


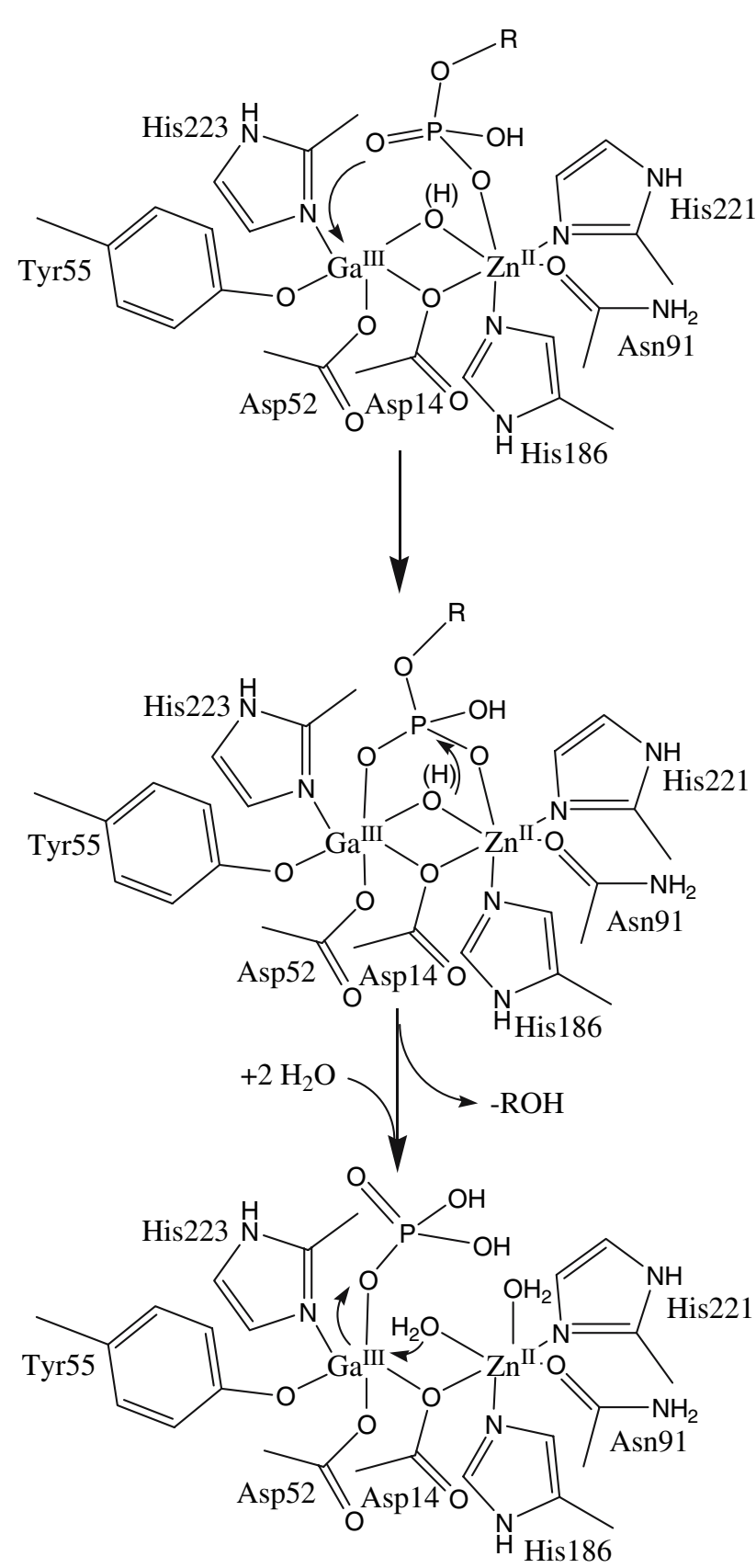

Scheme 1 Proposed mechanisms for purple acid phosphatase (PAP) catalyzed phosphorolysis. Amino acid residue and metal ion labels refer to the $\mathrm{Ga}$ (III)Zn(II) derivative of uteroferrin [15]. In one model, the initial coordination of the substrate to the divalent metal ion is followed by a nucleophilic attack by the $\mu$-(hydr)oxide. Following the release of the alcohol product $(R O H)$ a minimum of two water molecules are required to regenerate the active site. In an alternative scheme a terminal, Fe(III)-bound hydroxide is believed to be the nucleophile (see text for details). (Adapted from [15])

Biomimetics provide an additional method to probe the role of a metal ion in a catalytic cycle. A series of isostructural $\mathrm{Fe}(\mathrm{III}) \mathrm{M}$ (II) complexes ( $\mathrm{M}$ is $\mathrm{Fe}, \mathrm{Mn}, \mathrm{Cu}, \mathrm{Zn}$ ) that mimic the coordination environment of PAPs, and that have the characteristic purple/pink color, have recently been described [24-31]. Of particular interest is the observation that at least in the $\mathrm{Fe}(\mathrm{III}) \mathrm{Zn}$ (II) complex, the best characterized of these mimics, only the terminal, $\mathrm{Fe}(\mathrm{III})$-bound hydroxide is sufficiently strong a nucleophile to induce catalysis [28]. Thus, the proposed reaction mechanism for the mimetic is similar to that employed by native Uf and its $\mathrm{Fe}(\mathrm{III}) \mathrm{Zn}$ (II) derivative (Scheme 1). Here, we report physicochemical properties for relevant $\mathrm{Ni}$ (II) derivatives, and compare them with those of both the isostructural complexes and the corresponding $\mathrm{Fe}(\mathrm{III}) \mathrm{Ni}(\mathrm{II})$ derivative of Uf, Fe(III)Ni(III)-Uf. Implications for the catalytic activity are discussed.

\section{Materials and methods}

\section{Materials}

All reagents were of analytical grade and were purchased from Sigma-Aldrich unless otherwise stated.

\section{Purification and characterization of Uf}

Uf was extracted from the uterine fluid of a pregnant sow as described elsewhere [32]. Protein concentrations were determined by measuring the absorbance at $280 \mathrm{~nm}$ using the specific absorbance of 1.41 for a $1 \mathrm{mg} \mathrm{mL}^{-1}$ solution of Uf $\left(\varepsilon=49,350 \mathrm{M}^{-1} \mathrm{~cm}^{-1}\right)$. The rates of product formation using Uf were determined at $298 \mathrm{~K}$ using a continuous assay with pNPP as the substrate. Assays were undertaken at $\mathrm{pH}$ values between 3.8 and 7.0, using $100 \mathrm{mM}$ glycine, acetate or 2-morpholinoethanesulfonic acid (MES) buffer. Product (para-nitrophenol, pNP) formation was monitored at $390 \mathrm{~nm}$. Substrate concentrations ranged from 0.1 to $10 \mathrm{mM}$. Assays were performed with a Varian Cary50 $\mathrm{UV}-\mathrm{vis}$ spectrophotometer with $1-\mathrm{cm}$ pathlength quartz cuvettes.

Preparation of the $\mathrm{Fe}(\mathrm{III}) \mathrm{Ni}(\mathrm{II})$ metal ion derivative of Uf [Fe(III)Ni(II)-Uf]

In order to prepare half apoenzyme Uf $(500 \mu \mathrm{L}$ of $16 \mathrm{mg} \mathrm{mL}^{-1}$ in acetate buffer, $\mathrm{pH} 4.90$ ), $5 \mathrm{mM} \mathrm{1,10-phe-}$ nanthroline and $100 \mathrm{mM}$ sodium dithionite were mixed $\left(V_{\text {tot }}=3 \mathrm{~mL}\right)$ and incubated at room temperature for $1 \mathrm{~min}$. Subsequently, the mixture was loaded onto a 3-mL Bio-Rad Econo-Pac 10 DG column (pre-equilibrated with acetate buffer, $\mathrm{pH} 4.90$ ). To the half apoenzyme 100 equiv of $\mathrm{Ni}(\mathrm{II})$ [as $\mathrm{Ni}(\mathrm{OAc})_{2}$ ] was added and the mixture was incubated at room temperature for several days. The 
activity of the enzyme was monitored periodically and after maximum activity was reached, the excess metal ions were removed by dialysis. Metal ion analysis by atomic absorption spectroscopy indicated a stoichiometric amount of iron and $0.8 \mathrm{Ni}$ (II) ions per active site, and only trace amounts of $\mathrm{Zn}(\mathrm{II}), \mathrm{Cu}(\mathrm{II})$ and $\mathrm{Mn}(\mathrm{II})$.

Preparation of biomimetic complexes

(Caution! Perchlorate salts of metal complexes are potentially explosive and therefore should be prepared in small quantities.)

The ligand 2-bis[\{(2-pyridylmethyl)aminomethyl $\}-6-$ $\{(2$-hydroxybenzyl)(2-pyridylmethyl) $\}$ aminomethyl]-4-methylphenol $\left(\mathrm{H}_{2}\right.$ bpbpmp; Fig. 2) and the complex [FeNi (bpbpmp) $\left.(\mu \text {-OAc })_{2}\right]\left(\mathrm{ClO}_{4}\right)$ (1) were prepared as described previously [29-31].

\section{Preparation of $\left[\mathrm{Fe}(\mathrm{III}) \mathrm{Ni}(\mathrm{II})(\mathrm{bpbpmp})(\mu-\mathrm{OAc})\left(\mathrm{H}_{2} \mathrm{O}\right)_{2}\right]$} $\left[\mathrm{ClO}_{4}\right]_{2} \cdot 2 \mathrm{H}_{2} \mathrm{O}(2)$

A violet solution was obtained when $0.36 \mathrm{~g}(1 \mathrm{mmol})$ of $\mathrm{Ni}\left(\mathrm{ClO}_{4}\right)_{2}, 0.51 \mathrm{~g}$ of $\mathrm{Fe}\left(\mathrm{ClO}_{4}\right)_{3} \cdot 9 \mathrm{H}_{2} \mathrm{O}(1 \mathrm{mmol})$ and $0.13 \mathrm{~g}$ of $\mathrm{NaOAc} \cdot 3 \mathrm{H}_{2} \mathrm{O}(1 \mathrm{mmol})$ were added to a solution of $0.54 \mathrm{~g}$ ( $1 \mathrm{mmol})$ of the unsymmetric ligand $\mathrm{H}_{2} \mathrm{bpbpmp}$ [24] in $20 \mathrm{~mL}$ of methanol, at $333 \mathrm{~K}$. The microcrystalline precipitate was recrystallized in an ethyl acetate/methanol $(1: 1 \mathrm{v} / \mathrm{v})$ solution and crystals of [Fe(III)Ni(II)(bpbpmp) $(\mu$ OAc) $\left.\left(\mathrm{H}_{2} \mathrm{O}\right)_{2}\right]\left(\mathrm{ClO}_{4}\right)_{2} \cdot 2 \mathrm{H}_{2} \mathrm{O}(2)$ suitable for $\mathrm{X}$-ray analysis were obtained. Yield: $0.97 \mathrm{~g}(98 \%)$. Anal. Calcd for $\mathrm{C}_{36} \mathrm{H}_{45} \mathrm{Cl}_{2} \mathrm{~N}_{5} \mathrm{O}_{16} \mathrm{FeNi}$ : C 43.76, H 4.59, N 7.09. Found: $\mathrm{C}$ 43.3, H 4.5, N 7.0\%.

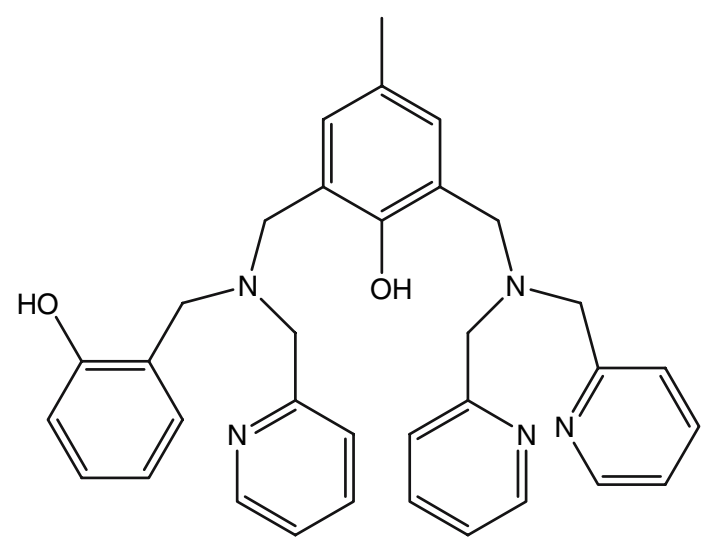

Fig. 2 2-Bis[ $\{(2-$-pyridylmethyl $)$ aminomethyl $\}-6-\{(2$-hydroxybenzyl)(2-pyridylmethyl)\} aminomethyl]-4-methylphenol ( $\mathrm{H}_{2}$ bpbpmp)
Preparation of $\left[\mathrm{Fe}(\mathrm{III}) \mathrm{Ni}(\mathrm{II})(\right.$ bpbpmp $\left.)(\mathrm{OH})\left(\mathrm{H}_{2} \mathrm{O}\right)_{3}\right]$ $\left(\mathrm{ClO}_{4}\right)_{2} \cdot 3 \mathrm{H}_{2} \mathrm{O}(3)$

To a methanolic solution containing $0.17 \mathrm{~g}$ of complex $\mathbf{1}$, $1.58 \mathrm{~mL}$ of an aqueous solution of $\mathrm{LiOH}\left(0.30 \mathrm{~mol} \mathrm{~L} \mathrm{~L}^{-1}\right)$ was added. The formation of [Fe(III)Ni(II)(bpbpmp) $\left.(\mathrm{OH})\left(\mathrm{H}_{2} \mathrm{O}\right)_{3}\right]\left(\mathrm{ClO}_{4}\right)_{2} \cdot 3 \mathrm{H}_{2} \mathrm{O}(3)$ was followed by observing the spectroscopic changes. A red microcrystalline precipitate was formed and, after recrystallization in methanol, crystals suitable for $\mathrm{X}$-ray analysis were obtained. Yield: $0.14 \mathrm{~g}(76 \%)$. Anal. Calcd for $\mathrm{C}_{34} \mathrm{H}_{46} \mathrm{Cl}_{2} \mathrm{~N}_{5} \mathrm{O}_{17} \mathrm{FeNi}: \mathrm{C}$ 41.58, H 4.72, N 7.13. Found: $\mathrm{C} 42.0, \mathrm{H} 4.7, \mathrm{~N} 7.2 \%$. Complex 3 can also be obtained by reacting $0.54 \mathrm{~g}$ (1 mmol) of $\mathrm{H}_{2}$ bpbpmp previously dissolved in $20 \mathrm{~mL}$ of methanol $(333 \mathrm{~K})$, with $0.36 \mathrm{~g}(1 \mathrm{mmol})$ of $\mathrm{Ni}\left(\mathrm{ClO}_{4}\right)_{2}$. $6 \mathrm{H}_{2} \mathrm{O}$ and $0.51 \mathrm{~g}(1 \mathrm{mmol})$ of $\mathrm{Fe}\left(\mathrm{ClO}_{4}\right)_{3} \cdot 9 \mathrm{H}_{2} \mathrm{O}$ followed by the addition of sodium perchlorate dissolved in water $(0.11 \mathrm{~g}, 1 \mathrm{mmol})$ under stirring and heating. Crystals suitable for X-ray analysis were obtained after allowing the solution to stand. Yield: $0.64 \mathrm{~g}$ (70\%). Anal. Calcd for $\mathrm{C}_{34} \mathrm{H}_{46} \mathrm{Cl}_{2} \mathrm{~N}_{5} \mathrm{O}_{17} \mathrm{FeNi}$ : C 41.58, $\mathrm{H}$ 4.72, N 7.13. Found: $\mathrm{C}$ 41.3, H 4.6, N 7.1\%.

Potentiometric titrations of biomimetic complexes

The potentiometric studies were carried out with a Micronal $\mathrm{B} 375 \mathrm{pH}$ meter fitted with blue-glass and calomel reference electrodes calibrated to read $-\log \left[\mathrm{H}^{+}\right]$directly, designated as $\mathrm{pH}$. Double-distilled water in the presence of $\mathrm{KMnO}_{4}$ and reagent-grade ethanol were used to prepare the ethanol/water $(70: 30, \mathrm{v} / \mathrm{v})$ solutions. The electrode was calibrated using the data obtained from the potentiometric titration of a known volume of a standard $0.100 \mathrm{M} \mathrm{HCl}$ solution with a standard $0.100 \mathrm{M} \mathrm{KOH}$ solution. The ionic strength of the $\mathrm{HCl}$ solution was maintained at $0.100 \mathrm{M}$ by addition of $\mathrm{KCl}$. The measurements were carried out in a thermostated cell containing a solution of the complex $(0.05 \mathrm{~mol}$ per $50 \mathrm{~mL})$ with ionic strength adjusted to $0.100 \mathrm{M}$ by addition of $\mathrm{KCl}$, at $298.00 \pm 0.05 \mathrm{~K}$. The experiments were performed under argon flow to eliminate the presence of atmospheric $\mathrm{CO}_{2}$. The samples were titrated by addition of fixed volumes of a standard $\mathrm{CO}_{2}$-free $\mathrm{KOH}$ solution $(0.100 \mathrm{M})$. Computations were carried out with the BEST program, and species diagrams were plotted with SPE and SPEPLOT programs [33].

X-ray crystallographic analysis of biomimetic complexes

The data were collected with a CAD-4 diffractometer using the $\omega-2 \theta$ scan method. Data reduction was carried 
out with HELENA [34] and an empirical absorption correction ( $\Psi$ scan) was performed with PLATON $[35,36]$. The structures were solved by direct methods and refined by full-matrix least-squares methods using SHELXS-97 [37] and SHELXL-97 [38] programs, respectively. The hydrogen atoms of the water solvates were found from a Fourier difference map and treated with a riding model. The hydrogen atoms bonded to carbon atoms were placed at idealized positions using standard geometric criteria. Non-hydrogen atoms were refined with anisotropic displacement parameters, except for the oxygen atoms of the perchlorate counterion for $\mathbf{3}$, which was disordered, with three oxygen atoms occupying two alternative positions. Crystal data are listed in Table 1; selected bond distances and angles are given in Tables 2 and 3. Crystallographic data (without structure factors) for the structure(s) reported in this paper have been deposited with the Cambridge Crystallographic Data Centre (CCDC) as supplementary publication nos.
CCDC-654237 and CCDC-654238. Copies of the data can be obtained free of charge from the CCDC (12 Union Road, Cambridge CB2 1EZ, UK; Tel.: +44-1223-336408; Fax: +44-1223-336033; e-mail: deposit@ccdc.cam.ac.uk; Web site http://www.ccdc.cam.ac.uk).

Magnetic susceptibility of biomimetic complexes

Magnetic susceptibility measurements were carried out at the School of Chemistry, Monash University, Australia, using a Quantum Design MPMS SQUID magnetometer with an applied field of $1 \mathrm{~T}$ as a function of temperature (ranging from 2 to $300 \mathrm{~K}$ ). The crystalline samples were enclosed in a calibrated gelatine capsule positioned in the center of a drinking straw fixed to the end of the sample rod. Effective magnetic moments, per mole, were calculated using the relationship $\mu_{\mathrm{eff}}=2.828\left(\chi_{\mathrm{m}} T\right)^{1 / 2}$, where $\chi_{\mathrm{m}}$ is the susceptibility per mole of complex.
Table 1 Crystallographic and refinement data for $\mathrm{Fe}(\mathrm{III}) \mathrm{Ni}(\mathrm{III})(\mathrm{bpbpmp})(\mu$ $\left.\mathrm{OAc})\left(\mathrm{H}_{2} \mathrm{O}\right)_{2}\right]\left(\mathrm{ClO}_{4}\right)_{2} \cdot 2 \mathrm{H}_{2} \mathrm{O}(2)$ and [Fe(III)Ni(II)(bpbpmp) $\left.(\mathrm{OH})\left(\mathrm{H}_{2} \mathrm{O}\right)_{3}\right]\left(\mathrm{ClO}_{4}\right)_{2} \cdot 3 \mathrm{H}_{2} \mathrm{O}(3)$

$\mathrm{H}_{2}$ bpbpmp is 2-bis[\{(2pyridylmethyl)aminomethyl $\}-6$ \{(2-hydroxybenzyl)(2pyridylmethyl) \}aminomethyl]4-methylphenol

\begin{tabular}{|c|c|c|}
\hline & 2 & 3 \\
\hline Empirical formula & $\mathrm{C}_{36} \mathrm{H}_{44} \mathrm{Cl}_{2} \mathrm{~N}_{5} \mathrm{O}_{16} \mathrm{FeNi}$ & $\mathrm{C}_{34} \mathrm{H}_{44} \mathrm{Cl}_{2} \mathrm{~N}_{5} \mathrm{O}_{16} \mathrm{FeNi}$ \\
\hline Formula weight & 988.22 & 964.20 \\
\hline Temperature (K) & $293(2)$ & $293(2)$ \\
\hline Wavelength $(\AA)$ & 0.71073 & 0.71073 \\
\hline Crystal system & Monoclinic & Triclinic \\
\hline Space group & $P 2_{1} / n$ & $P-1$ \\
\hline$a(\AA)$ & $11.233(2)$ & $11.257(2)$ \\
\hline$b(\AA)$ & $13.942(3)$ & $12.813(3)$ \\
\hline$c(\AA)$ & $27.593)(5)$ & $15.506(3)$ \\
\hline$\alpha\left({ }^{\circ}\right)$ & & $103.77(3)$ \\
\hline$\beta\left(^{\circ}\right)$ & $98.61(3)$ & $99.52(3)$ \\
\hline$\gamma\left({ }^{\circ}\right)$ & & $93.43(3)$ \\
\hline Volume $\left(\AA^{3}\right)$ & $4,272.7$ & $2,130.8$ \\
\hline$Z$ & 4 & 2 \\
\hline$D_{\text {calc }}\left(\mathrm{mg} \mathrm{m}^{-3}\right)$ & 1.536 & 1.503 \\
\hline$\mu\left(\mathrm{mm}^{-1}\right)$ & 0.981 & 0.981 \\
\hline$F(000)$ & 2,044 & 998 \\
\hline$\Theta\left({ }^{\circ}\right)$ & $2.54-25.07$ & $2.40-25.07$ \\
\hline \multirow[t]{3}{*}{ Index ranges } & $-13 \leq h \leq 13$ & $0 \leq h \leq 13$ \\
\hline & $-16 \leq k \leq 0$ & $-15 \leq k \leq 15$ \\
\hline & $-32 \leq l \leq 0$ & $-18 \leq l \leq 18$ \\
\hline Reflections collected & 7,750 & 7,980 \\
\hline Independent reflection & $7,548\left[R_{(\mathrm{int})}=0.0287\right]$ & $7,557\left[R_{\text {(int) }}=0.0142\right]$ \\
\hline Refinement method & Full-matrix least squares on $F^{2}$ & Full-matrix least squares on $F^{2}$ \\
\hline Data/restraints/parameters & $7,584 / 0 / 550$ & $7,557 / 48 / 530$ \\
\hline Goodness of fit on $F^{2}$ & 1.048 & 1.045 \\
\hline Final $R$ indices $[I>2 \sigma(I)]$ & $R_{1}=0.0494, \mathrm{wR}_{2}=0.1307$ & $R_{1}=0.0513, \mathrm{wR}_{2}=0.1474$ \\
\hline$R$ indices (all data) & $R_{1}=0.1005, w R_{2}=0.1650$ & $R_{1}=0.0880, \mathrm{wR}_{2}=0.1681$ \\
\hline $\begin{array}{l}\text { Largest diffraction peak } \\
\text { and hole }\left(e \AA^{-3}\right)\end{array}$ & 0.958 and -0.790 & 0.745 and -0.619 \\
\hline
\end{tabular}


Table 2 Selected bond distances (Ångstrom) and angles (degrees) for 2

\begin{tabular}{lclr}
\hline Fe1-O20 & $1.902(3)$ & Fe1-O61 & $1.973(3)$ \\
Fe1-O1 & $1.982(3)$ & Fe1-O1W & $2.103(3)$ \\
Fe1-N32 & $2.124(4)$ & Fe1-N1 & $2.175(4)$ \\
Fe1-Ni1 & $3.5166(11)$ & Ni1-N52 & $2.054(4)$ \\
Ni1-O2W & $2.061(3)$ & Ni1-N42 & $2.073(4)$ \\
Ni1-O62 & $2.074(3)$ & Ni1-N4 & $2.087(4)$ \\
Ni1-O1 & $2.095(3)$ & & \\
O20-Fe1-O61 & $95.16(15)$ & O20-Fe1-O1 & $99.01(14)$ \\
O61-Fe1-O1 & $93.68(13)$ & O20-Fe1-O1W & $89.89(15)$ \\
O61-Fe1-O1W & $88.21(14)$ & O1-Fe1-O1W & $170.69(14)$ \\
O20-Fe1-N32 & $167.23(15)$ & O61-Fe1-N32 & $96.29(15)$ \\
O1-Fe1-N32 & $85.90(13)$ & O1W-Fe1-N32 & $84.83(14)$ \\
O20-Fe1-N1 & $89.35(16)$ & O61-Fe1-N1 & $173.21(15)$ \\
O1-Fe1-N1 & $90.62(14)$ & O1W-Fe1-N1 & $86.72(15)$ \\
N32-Fe1-N1 & $78.77(15)$ & N52-Ni1-O2W & $92.97(16)$ \\
N52-Ni1-N42 & $95.65(16)$ & O2W-Ni1-N42 & $94.08(16)$ \\
N52-Ni1-O62 & $174.64(15)$ & O2W-Ni1-O62 & $91.71(14)$ \\
N42-Ni1-O62 & $86.62(15)$ & N52-Ni1-N4 & $83.14(16)$ \\
O2W-Ni1-N4 & $173.03(14)$ & N42-Ni1-N4 & $80.60(17)$ \\
O62-Ni1-N4 & $92.46(14)$ & N52-Ni1-O1 & $87.89(14)$ \\
O2-W Ni1-O1 & $93.32(13)$ & N42-Ni1-O1 & $171.61(15)$ \\
O62-Ni1-O1 & $89.22(13)$ & N4-Ni1-O1 & $92.31(14)$ \\
Fe1-O1-Ni1 & $119.17(15)$ & & \\
\hline & & & \\
\hline
\end{tabular}

Kinetic assays of $\mathrm{Fe}(\mathrm{III}) \mathrm{Ni}(\mathrm{II})-\mathrm{Uf}$ and biomimetic complexes

For $\mathrm{Fe}(\mathrm{III}) \mathrm{Ni}(\mathrm{II})$-Uf all kinetic experiments were conducted with a Varian Cary50 UV-vis spectrophotometer at $298 \mathrm{~K}$ unless specified otherwise, using 1-mL quartz cuvettes with 1-cm pathlength. A continuous assay was used to determine kinetic constants for Uf with pNPP as the substrate. The rate of formation of product $(\mathrm{pNP})$ was measured at $390 \mathrm{~nm}$ over $1 \mathrm{~min}$. The extinction coefficient of pNP in $0.1 \mathrm{M}$ acetate buffer ( $\mathrm{pH} 4.90)$ was determined as $342.9 \mathrm{M}^{-1} \mathrm{~cm}^{-1}$. Different concentrations of substrates, ranging from 0.5 to $10 \mathrm{mM}$, were assayed in $1 \mathrm{~mL}$ reaction mixtures in $0.1 \mathrm{M}$ acetate buffer, $\mathrm{pH} 4.9$ (final enzyme concentration $50 \mathrm{nM}$ ). Assay mixtures were incubated at $298 \mathrm{~K}$ for $2 \mathrm{~min}$ prior to the addition of enzyme. Data were analyzed using WinCurveFit (Kevin Raner Software). A range of buffers (100 $\mathrm{mM}$ acetate and MES) were used to cover the $\mathrm{pH}$ regions $3.8-5.5$ and 5.2-7.0, respectively. The change in molar absorption coefficient at $390 \mathrm{~nm}, \Delta \varepsilon$, was determined at each $\mathrm{pH}$ in experiments in which pNPP $(5 \mathrm{mM})$ was hydrolyzed to completion (enzyme concentration $2 \mu \mathrm{M}$ ) at room temperature. The solution of $\mathrm{pNP}$ which resulted from this reaction was diluted in buffer to a concentration of $0.2 \mathrm{mM} \mathrm{pNP}$, and the absorbances of the
Table 3 Selected bond distances (Ångstrom) and angles (degrees) for 3

\begin{tabular}{lrlr}
\hline Ni1-Fe1 & $3.6838(14)$ & Ni1-O4W & $2.026(3)$ \\
Ni1-N42 & $2.057(4)$ & Ni1-N52 & $2.064(4)$ \\
Ni1-N4 & $2.069(4)$ & Ni1-O3W & $2.106(3)$ \\
Ni1-O10 & $2.161(3)$ & Fe1-O20 & $1.911(3)$ \\
Fe1-O1W & $1.916(3)$ & Fe1-O10 & $2.007(3)$ \\
Fe1-O2W & $2.077(3)$ & Fe1-N32 & $2.131(4)$ \\
Fe1-N1 & $2.167(4)$ & & \\
O4W-Ni1-N42 & $95.37(15)$ & O4W-Ni1-N52 & $95.52(15)$ \\
N42-Ni1-N52 & $96.46(16)$ & O4W Ni1-N4 & $175.50(14)$ \\
N42-Ni1-N4 & $83.62(16)$ & N52-Ni1-N4 & $80.26(16)$ \\
O4W-Ni1-O3W & $90.36(14)$ & N42-Ni1-O3W & $171.71(14)$ \\
N52-Ni1-O3W & $88.92(15)$ & N4-Ni1-O3W & $91.11(15)$ \\
O4W-Ni1-O10 & $92.13(13)$ & N42-Ni1-O10 & $85.57(13)$ \\
N52-Ni1-O10 & $171.85(14)$ & N4-Ni1-O10 & $92.16(13)$ \\
O3W-Ni1-O10 & $88.24(13)$ & O20-Fe1-O1W & $97.38(14)$ \\
O20-Fe1-O10 & $97.98(14)$ & O1W-Fe1-O10 & $89.92(12)$ \\
O20-Fe1-O2W & $89.83(14)$ & O1W-Fe1-O2W & $88.73(13)$ \\
O10-Fe1-O2W & $172.18(13)$ & O20-Fe1-N32 & $166.78(15)$ \\
O1W-Fe1-N32 & $94.25(14)$ & O10-Fe1-N32 & $88.29(14)$ \\
O2W-Fe1-N32 & $84.14(15)$ & O20-Fe1-N1 & $89.52(15)$ \\
O1W-Fe1-N1 & $172.14(14)$ & O10-Fe1-N1 & $92.85(14)$ \\
O2W-Fe1-N1 & $87.53(14)$ & N32-Fe1-N1 & $78.50(15)$ \\
Fe1-O10-Ni1 & $124.20(14)$ & & \\
\hline
\end{tabular}

mixtures were measured against $0.2 \mathrm{mM}$ pNPP in each buffer at a wavelength of $390 \mathrm{~nm}$.

For the biomimetic systems phosphatase-like activity was determined by measuring hydrolysis of the substrate 2,4-bis(dinitrophenyl)phosphate (2,4-bdNPP) at $400 \mathrm{~nm}$ $\left(\varepsilon=12,100 \mathrm{M}^{-1} \mathrm{~cm}^{-1}\right.$ ) [29]. Reactions were monitored to less than $5 \%$ of conversion of substrate to product, and the data were treated by the initial rate method. The effect of $\mathrm{pH}$ on the rate of hydrolysis of 2,4-bdNPP between $\mathrm{pH} 3.0$ and 9.0 was investigated by using fixed concentrations of substrate $(2.0 \mathrm{mM})$ and complex $\left(4.0 \times 10^{-5} \mathrm{M}\right)$. The complex was preincubated $(10 \mathrm{~min})$ by diluting a stock solution of the complex in the appropriate buffer at the desired $\mathrm{pH}$ at $298 \mathrm{~K}\left(I=0.05 \mathrm{M}\right.$ with $\left.\mathrm{LiClO}_{4}\right)$. Substrate dependence of the catalytic rate was measured at optimum $\mathrm{pH}(\mathrm{pH}$ 6.8) and analyzed by nonlinear regression and a Lineweaver-Burk plot (both methods resulted in, within experimental error, identical parameters).

Spectroscopic measurements of $\mathrm{Fe}(\mathrm{III}) \mathrm{Ni}(\mathrm{II})-\mathrm{Uf}$ and biomimetic complexes

X-ray absorption data collection was performed at KEK, Tskuba, beamline BL-20B. Data were collected for both the 
solid and the dissolved state of $\mathbf{3}$ (70:30 acetonitrile/water solution at a concentration of approximately $1 \mathrm{mM}$ ) in fluorescence mode at $10 \mathrm{~K}$. In the solid state the sample was mixed with boron nitride at an appropriate concentration for a $70 \%$ edge drop. X-ray absorption spectra at the iron K-edge were collected between 6.89 and $8.00 \mathrm{keV}$. The extended Xray absorption fine structure (EXAFS) was obtained after background removal using the program Athena [39]. Further data analysis was carried out with the program Artemis [39], where the $k^{3}$-weighted data were fitted to a model based on atom shells. For each shell the average bond distance and Debye-Waller factor were fitted using single-scattering EXAFS theory based on FEFF 6.0. These parameters were restrained to physically reasonable values.

Electronic absorption spectra were collected with a Varian Cary50 spectrophotometer at $298 \mathrm{~K}$ in the range 250-800 nm, with the biomimetics dissolved in acetonitrile and the $\mathrm{Fe}(\mathrm{III}) \mathrm{Ni}$ (II) derivative of Uf in $100 \mathrm{mM}$ acetate buffer, pH 4.9. Magnetic circular dichroism (MCD) measurements were conducted with a Spex1402 monochromator equipped with an SM-4 Oxford magneto-optical cryostat. A Varian SpectrAA 220FS atomic absorption spectrometer was used to determine the concentration of protein-bound metal ions.

Cyclic voltammetry of Fe(III)Ni(II)-Uf and biomimetic complexes

Electrochemical measurements with $\mathrm{Fe}(\mathrm{III}) \mathrm{Ni}(\mathrm{II})-\mathrm{Uf}$ were conducted with a BAS 100B/W electrochemical analyzer and a BAS C3 cell stand. The electrode used was an edge plane pyrolytic graphite working electrode prepared as described elsewhere [3]. A platinum wire was used as the counter electrode and the reference electrode was $\mathrm{Ag} / \mathrm{AgCl}$ for all experiments. The potentials reported herein are versus the normal hydrogen electrode (NHE), achieved using a 196-mV correction for the potential of the reference electrode. The working electrode film was prepared by combining $10 \mu \mathrm{L}$ of a $300 \mu \mathrm{M}$ protein solution with $10 \mu \mathrm{L}$ of $5 \mathrm{mM}$ dimethyldidodecylammonium bromide in a sample tube. A $10-\mu \mathrm{L}$ aliquot of this solution was subsequently added to the electrode surface and dried overnight at $277 \mathrm{~K}$. Electrochemical measurements were conducted at $298 \mathrm{~K}$ in $500 \mu \mathrm{L}$ of a mixed buffer solution containing $100 \mathrm{mM}$ sodium acetate, $100 \mathrm{mM}$ MES and $100 \mathrm{mM}$ glycine. The $\mathrm{pH}$ range 3.1-7.0 was achieved through titration of appropriate amounts of sodium hydroxide, acetic acid or hydrochloric acid. The cyclic voltammetry scan rates were between 20 and $200 \mathrm{mV} \mathrm{s}^{-1}$ and the square wave voltammetry had a 2$\mathrm{mV}$ step potential, 8-mV amplitude and a frequency of $5 \mathrm{~Hz}$.

For the biomimetic complexes cyclic voltammograms were recorded with a Princeton Applied Research 273 system at room temperature under an argon atmosphere in organic solvents, with tetrabutylammonium hexafluorophosphate as the supporting electrolyte. The experiments were carried out by employing a standard three-component system: a platinum working electrode; a platinum wire auxiliary electrode; an $\mathrm{Ag} / \mathrm{AgCl}$ pseudoreference electrode. To monitor the reference electrode, the ferrocenium/ferrocene $\left(\mathrm{Fc}^{+} / \mathrm{Fc}\right)$ couple was used; potentials are reported relative to the $\mathrm{Fc} / \mathrm{Fc}^{+}$couple. Typically, scan rates of 50, 75 and $100 \mathrm{mV} \mathrm{s}^{-1}$ were employed.

\section{Results and discussion}

$\mathrm{Fe}(\mathrm{III}) \mathrm{Ni}(\mathrm{II})$ derivative of Uf; reconstitution of enzyme activity

Treatment of Uf with the reductant dithionite and the chelator 1,10-phenanthroline effectively removes the divalent iron, while the chromophoric trivalent iron remains largely bound to the protein. Metal ion analysis indicated that the half apoenzyme contained $0.85( \pm 0.06)$ Fe per active site, with a residual activity of $k_{\text {cat }}=1 \mathrm{~s}^{-1}$ (approximately $0.25 \%$ of the value determined for the fully active di-iron enzyme [40]). Reconstitution of enzyme activity following the addition of excess $\mathrm{Ni}(\mathrm{II})$ was monitored using the standard continuous assay at $\mathrm{pH} 4.90$. After $25 \mathrm{~h}$ of incubation the activity increase reached a plateau with a $k_{\text {cat }}$ of $6.3 \mathrm{~s}^{-1}$. After a lag period of approximately $24 \mathrm{~h}$ the activity started to rise further to a final activity of $k_{\text {cat }}=61.5 \mathrm{~s}^{-1}$ after approximately $200 \mathrm{~h}$. The result suggests biphasic behavior where initial rapid metal ion uptake is followed by a slower conformational rearrangement of the active site in order to adopt a structure optimal for catalytic transformations. In order to test this hypothesis, an aliquot of half apoenzyme was incubated for $10 \mathrm{~h}$ with excess $\mathrm{Ni}(\mathrm{II})$. When the activity reached the initial plateau $\left(k_{\text {cat }}=6 \mathrm{~s}^{-1}\right)$ excess $\mathrm{Ni}$ (II) was removed by gel filtration and the metal ion content of the protein sample was determined to be 0.75 Fe and $0.72 \mathrm{Ni}$. A second aliquot of the half apoenzyme was incubated until maximum activity $\left(k_{\text {cat }}=61.5 \mathrm{~s}^{-1}\right)$ was reached (approximately $220 \mathrm{~h}$ ) and the metal ion content was determined to be $0.78 \mathrm{Fe}$ and $0.86 \mathrm{Ni}$, similar to that of the first aliquot, suggesting that metal ion uptake into the active site is relatively rapid but the reconstitution of a catalytically fully functional active site is slow.

Electronic absorption spectroscopy of $\mathrm{Fe}(\mathrm{III}) \mathrm{Ni}(\mathrm{II})-\mathrm{Uf}$

The major feature of the absorption spectrum of $\mathrm{Fe}(\mathrm{III})$ Ni(II)-Uf (Table 4) is a band at $275 \mathrm{~nm}$ attributed to the absorption of aromatic amino acids. Transitions observed 
Table 4 Spectroscopic, susceptibility, potentiometric and kinetic data for $\mathrm{Fe}(\mathrm{III}) \mathrm{Ni}(\mathrm{II})-\mathrm{Uf}$ (Uf is uteroferrin), $\left[\mathrm{FeNi}(\mathrm{bpbpmp})(\mu-\mathrm{OAc})_{2}\right]\left(\mathrm{ClO}{ }_{4}\right)$ 1, 2, 3 and related complexes

\begin{tabular}{|c|c|c|c|c|c|c|c|c|c|c|c|}
\hline \multirow{3}{*}{$\begin{array}{l}\mathrm{Fe}(\mathrm{III}) \mathrm{Fe}(\mathrm{II})-\mathrm{Uf}[2] \\
\mathrm{Fe}(\mathrm{III}) \mathrm{Ni}(\mathrm{II})-\mathrm{Uf}\end{array}$} & \multirow{3}{*}{$\begin{array}{l}\begin{array}{l}\lambda_{\max }(\mathrm{nm}) \\
\left(\varepsilon \mathrm{M}^{-1} \mathrm{~cm}^{-1}\right)\end{array} \\
510(4,450) \\
506(3,150) ; 330 ; \\
275(49,350)\end{array}$} & \multicolumn{4}{|c|}{$\mathrm{p} K_{\mathrm{e} 1} \mathrm{p} K_{\mathrm{e} 2} \mathrm{p} K_{\mathrm{es} 1} \mathrm{p} K_{\mathrm{es} 2}$} & \multirow{2}{*}{$\frac{K_{\mathrm{s}}(\mathrm{mM})}{1.2}$} & \multirow{2}{*}{$\begin{array}{l}k_{\text {cat }}\left(\mathrm{s}^{-1}\right) \\
431\end{array}$} & \multicolumn{4}{|l|}{$J\left(\mathrm{~cm}^{-1}\right)$} \\
\hline & & 2.3 & 4.8 & 4.2 & 6.1 & & & -5 to -11 & & & \\
\hline & & - & 5.6 & 4.9 & 5.9 & 1.4 & 61.5 & & & & \\
\hline & $\begin{array}{l}\lambda_{\max }(\mathrm{nm}) \\
\left(\varepsilon \mathrm{M}^{-1} \mathrm{~cm}^{-1}\right)\end{array}$ & $\mathrm{p} K_{\mathrm{a} 1}$ & $\mathrm{p} K_{\mathrm{a} 2}$ & $\mathrm{p} K_{\mathrm{a} 3}$ & & $K_{\mathrm{m}}(\mathrm{mM})$ & $k_{\text {cat }}\left(\mathrm{s}^{-1}\right)$ & $J\left(\mathrm{~cm}^{-1}\right)$ & $\begin{array}{l}E_{1 / 2}(\mathrm{~V}) \\
\mathrm{Fe}(\mathrm{III}) / \\
\mathrm{Fe}(\mathrm{II})\end{array}$ & $\begin{array}{l}E_{\mathrm{pc}}(\mathrm{V}) \\
\mathrm{Ni}(\mathrm{II}) / \\
\mathrm{Ni}(\mathrm{I})\end{array}$ & $\begin{array}{l}E_{1 / 2}(\mathrm{~V}) \\
\mathrm{Ni}(\mathrm{III}) / \\
\mathrm{Ni}(\mathrm{II})\end{array}$ \\
\hline 1 [22] & $\begin{array}{l}930(25) ; 538(4,813) \\
\quad 328(5,562)\end{array}$ & 5.30 & 6.80 & 8.61 & & $3.8 \times 10^{-3}$ & $4.8 \times 10^{-4}$ & $\begin{array}{c}-13.3\left(g_{\mathrm{Fe}}=1.98\right. \\
\left.g_{\mathrm{Ni}}=2.077\right)\end{array}$ & -0.94 & -1.41 & +0.76 \\
\hline 2 & $\begin{array}{l}930(10) ; 545(4,234) \\
\quad 321(5,700)\end{array}$ & 4.80 & 6.65 & 8.01 & & $1.1 \times 10^{-2}$ & $8.7 \times 10^{-4}$ & $\begin{array}{c}-13.2\left(g_{\mathrm{Fe}}=1.981,\right. \\
\left.g_{\mathrm{Ni}}=2.110\right)\end{array}$ & -0.48 & -0.98 & \\
\hline 3 & $\begin{array}{l}932(20) ; 522(2,603) \\
\quad 324(3,780)\end{array}$ & 4.30 & 4.90 & 8.10 & & $1.2 \times 10^{-2}$ & $9.0 \times 10^{-4}$ & $\begin{array}{c}-13.7\left(g_{\mathrm{Fe}}=1.98\right. \\
\left.g_{\mathrm{Ni}}=2.110\right)\end{array}$ & -0.58 & -1.22 & \\
\hline $\begin{array}{l}{[\mathrm{FeFe}(\mathrm{bpbpmp})} \\
\left.\quad(\mu-\mathrm{OAc})_{2}\right]^{+}[24]\end{array}$ & $1,050(60) ; 555(4,560)$ & & & & & & & -7.4 & -0.89 & & \\
\hline $\begin{array}{l}\text { [FeMn(bpbpmp) } \\
\left.\quad(\mu-\mathrm{OAc})_{2}\right]^{+}[25]\end{array}$ & $544(2,680)$ & & 5.80 & 7.76 & & $2.1 \times 10^{-3}$ & $7.1 \times 10^{-4}$ & -6.8 & -0.87 & & \\
\hline $\begin{array}{l}\text { [FeZn(bpbpmp) } \\
\left.\quad(\mu-\mathrm{OAc})_{2}\right]^{+}[27]\end{array}$ & $540(3,700)$ & 4.86 & 6.00 & 7.22 & & $8.1 \times 10^{-3}$ & $11.0 \times 10^{-4}$ & & -0.91 & & \\
\hline $\begin{array}{l}{[\mathrm{FeCu}(\mathrm{bpbpmp})} \\
\left.\quad(\mu-\mathrm{OAc})_{2}\right]^{+}[26]\end{array}$ & $546(3,400) ; 330$ & 5.25 & 6.20 & 7.82 & & $1.1 \times 10^{-2}$ & $18.0 \times 10^{-4}$ & & -1.0 & & \\
\hline $\begin{array}{l}{\left[\mathrm{Ni}_{2}(\mathrm{Hbpbpmp})\right.} \\
\left.\quad(\mu-\mathrm{OAc})_{2}\right]^{+}[59]\end{array}$ & & & & & & & & & & -1.24 & +0.59 \\
\hline
\end{tabular}

at 330 and $506 \mathrm{~nm}$ are associated with the characteristic charge transfer transition observed in PAPs; for example, $\mathrm{Fe}(\mathrm{III}) \mathrm{Fe}(\mathrm{II})-\mathrm{Uf}$ displays an absorption band at $510 \mathrm{~nm}[1$, $2,20]$. Other derivatives of Uf have similar $\lambda_{\max }$ and $\varepsilon$, ranging from $514 \mathrm{~nm}$ and $3,350 \mathrm{M}^{-1} \mathrm{~cm}^{-1}$ for the $\mathrm{Mn}$ (II) analog to $525 \mathrm{~nm}$ and $3,580 \mathrm{M}^{-1} \mathrm{~cm}^{-1}$ for $\mathrm{Fe}(\mathrm{III}) \mathrm{Zn}$ (II)-Uf [20], which suggests that the electronic structure of the chromophoric site in PAPs is well conserved.

\section{Electrochemical properties of Fe(III)Ni(II)-Uf}

The cyclic voltammogram of $\mathrm{Fe}(\mathrm{III}) \mathrm{Ni}(\mathrm{II})-\mathrm{Uf}$ at $\mathrm{pH} 5.0$ indicates a reversible redox potential at $557 \mathrm{mV}$. The linear dependence of the current on the scan rate is indicative of an electron transfer process localized on the electrode surface [3]. The absence of a shift in the potential over a range of scan rates, a constant peak width at half height and a reasonably uniform cathodic and anodic peak current suggests that electron transfer in $\mathrm{Fe}(\mathrm{III}) \mathrm{Ni}$ (II)-Uf is a rapid process unaffected by any coupled reactions. For comparative purposes voltammetric data were also collected for native Uf. Both sets of data show a linear $\mathrm{pH}$ dependence of the redox potentials; while the $\mathrm{pH}$ dependence of the redox potentials of the derivative is similar to that observed for the native enzyme, the potentials are shifted to approximately $180 \mathrm{mV}$ higher values. Since this potential is thus not likely to be due to the chromophoric Fe(III)/ $\mathrm{Fe}$ (II) couple, and since the M(II) site does not have strong electron donors to stabilize $\mathrm{Ni}$ (III) [41], it is hypothesized that the observed potential in the derivative is associated with the oxidation of the tyrosinate ligand involved in the formation of the ligand to metal charge transfer (LMCT) complex (Tyr55; Fig. 1). This redox reaction apparently is not observed in the native enzyme, possibly owing to the oxidation of the nonchromophoric iron. It has been shown that upon oxidation of native Uf to the inactive di-iron(III) form the strength of the tyrosine-Fe(III) bond is increased [12], which greatly stabilizes the tyrosine ligand in its reduced form (i.e., its redox potential is significantly increased).

\section{Kinetic properties of $\mathrm{Fe}(\mathrm{III}) \mathrm{Ni}(\mathrm{II})-\mathrm{Uf}$}

Previous metal replacement studies have shown that replacement of $\mathrm{Fe}$ (II) by $\mathrm{Zn}$ (II) in pig and bovine PAPs can be achieved without significant loss of activity [20, 42]. 
Replacement with $\mathrm{Mn}(\mathrm{II}), \mathrm{Cu}(\mathrm{II})$ and $\mathrm{Co}(\mathrm{II})$ leads to only partial reconstitution of enzyme activity [20, 21]. Similarly, the $\mathrm{Ni}(\mathrm{II})$ derivative of Uf reaches only approximately $15 \%$ of the activity of the native enzyme (Table 4). This reduction in activity is not likely to be due to variations in Lewis acidity between the divalent ions since $\mathrm{Cu}$ (II) and $\mathrm{Mn}$ (II) derivatives of Uf have activities similar to that of the $\mathrm{Ni}$ (II) derivative, despite the fact that $\mathrm{Cu}(\mathrm{II})$ and $\mathrm{Ni}(\mathrm{II})$ are stronger Lewis acids than $\mathrm{Fe}(\mathrm{II})$, which in turn is stronger than $\mathrm{Mn}(\mathrm{II})$ (the $\mathrm{p} K_{\mathrm{a}}$ values for hexaaqua complexes of $\mathrm{Cu}(\mathrm{II}), \mathrm{Ni}(\mathrm{II}), \mathrm{Fe}(\mathrm{II})$ and $\mathrm{Mn}$ (II) are 7.5, 9.4, 10.1 and 10.7, respectively [43]).

The $\mathrm{pH}$ dependences of $k_{\mathrm{cat}}$ and $k_{\mathrm{cat}} / K_{\mathrm{m}}$ for FeNi-Uf have been assessed (Fig. 3, Table 4). At least two protonation equilibria are relevant factors determining the reactivity $\left(k_{\text {cat }}\right)$, while for the catalytic efficiency $\left(k_{\mathrm{cat}} / K_{\mathrm{m}}\right)$ only the alkaline limb is resolved. The $\mathrm{pH}$ dependences of $k_{\text {cat }}$ and $k_{\text {cat }} / K_{\mathrm{m}}$ were analyzed using Eqs. 1 and 2 [44], and the $\mathrm{p} K_{\mathrm{a}}$ values for the relevant equilibria are listed in Table 4, together with the corresponding $\mathrm{p} K_{\mathrm{a}}$ values determined for native $\mathrm{Fe}(\mathrm{III}) \mathrm{Fe}$ (II)-Uf [40]. Note that Eqs. 1 and 2 were derived using diprotic and monoprotic models, respectively [44]. $K_{\text {es }}$ values represent protonation equilibria for the enzyme-substrate complex, and $K_{\mathrm{e}}$ is associated with a protonation equilibrium in the free enzyme or substrate. $K_{\mathrm{s}}$ describes the equilibrium of the interaction between enzyme and substrate.

$k_{\mathrm{cat}}(\mathrm{obs})=\frac{k_{\mathrm{cat}}}{1+\frac{\left[\mathrm{H}^{+}\right]}{K_{\mathrm{cs} 1}}+\frac{K_{\mathrm{co} 2}}{\left[\mathrm{H}^{+}\right]}}$

$\frac{k_{\mathrm{cat}}}{K_{\mathrm{m}}}(\mathrm{obs})=\frac{k_{\mathrm{cat}}}{K_{\mathrm{s}}\left(1+\frac{K_{\mathrm{c} 2}}{\left[\mathrm{H}^{+}\right]}\right)}$

In the comparison between the $\mathrm{Fe}$ (III)Fe(II) and $\mathrm{Fe}(\mathrm{III}) \mathrm{Ni}$ (II) forms of Uf the $\mathrm{p} K_{\mathrm{a}}$ least affected by the metal ion substitution is $\mathrm{p} K_{\mathrm{es} 2}$, suggesting that the corresponding equilibrium involves a residue which is not directly coordinated to the divalent metal ion. In agreement with previous studies [40, 45-47] $\mathrm{p} K_{\mathrm{es} 2}$ is assigned to a conserved histidine residue in the second coordination sphere, which is likely to act as a proton donor to the leaving alcohol group during catalysis [14, 47-49]. Site-directed mutagenesis studies identified His92 as the likely residue [47]. In the protonated form the imidazole side chains are positively charged, thus increasing the binding affinity of the negatively charged phosphate group of the substrate. Deprotonation of the imidazole group leads to a loss of positive charge, consistent with the observed increase in $K_{\mathrm{m}}$ at high $\mathrm{pH}$.

The remaining $\mathrm{p} K_{\mathrm{a}}$ values $\left(\mathrm{p} K_{\mathrm{es} 1}\right.$ and $\left.\mathrm{p} K_{\mathrm{e} 2}\right)$ are significantly altered by the metal ion substitution (Table 4), as
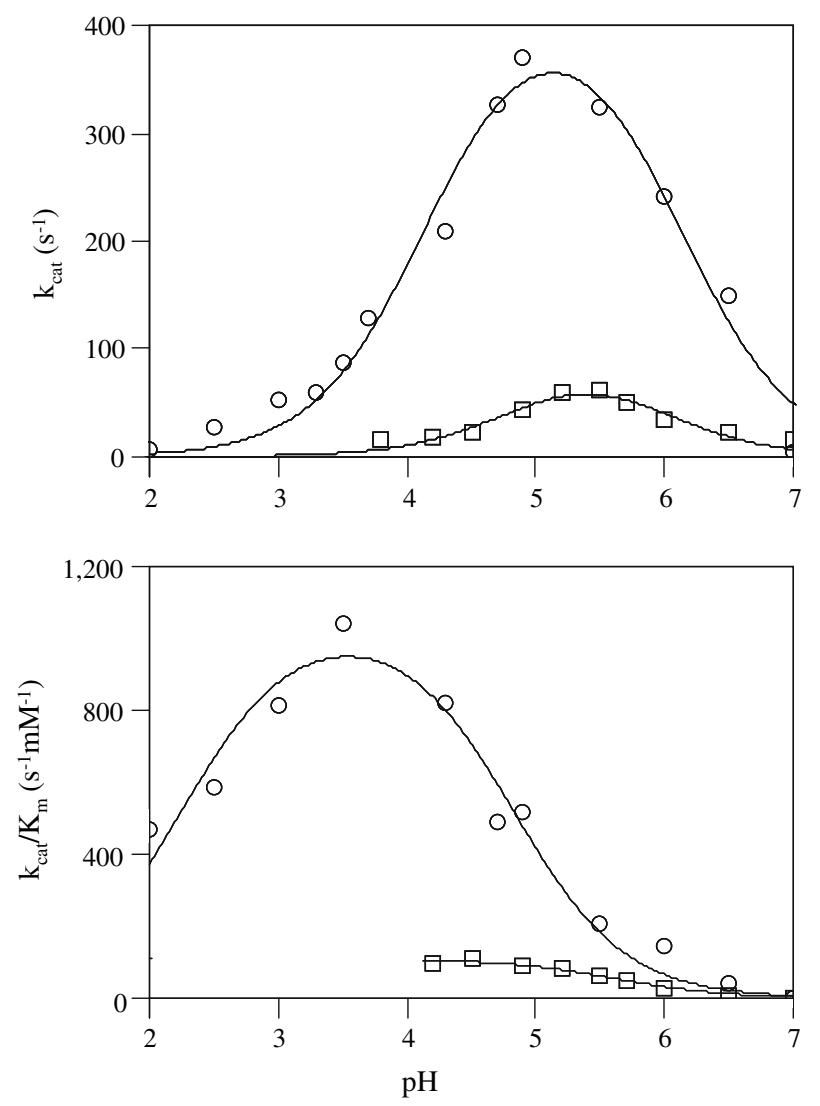

Fig. 3 pH dependence of the kinetic parameters of $\mathrm{Fe}(\mathrm{III}) \mathrm{Ni}(\mathrm{II})-\mathrm{Uf}$. The data for the $\mathrm{Fe}(\mathrm{III}) \mathrm{Ni}(\mathrm{II})$ derivative of Uf (squares) were compared with those reported for the native $\mathrm{Fe}(\mathrm{III}) \mathrm{Fe}(\mathrm{II})$ form (circles) [40]. The data were fitted using Eqs. 1 and 2

would be expected for protonation equilibria of ligands that are directly coordinated to the divalent metal ion. In comparison with the native $\mathrm{Fe}(\mathrm{III}) \mathrm{Fe}$ (II) form of Uf each $\mathrm{p} K_{\mathrm{a}}$ in the $\mathrm{Fe}(\mathrm{III}) \mathrm{Ni}(\mathrm{II})$ derivative is shifted towards more alkaline values, resulting in a corresponding shift of the $\mathrm{pH}$ for optimum reactivity from 5.0 to 5.5 upon replacing $\mathrm{Fe}$ (II) with $\mathrm{Ni}(\mathrm{II})$. Based on an inspection of the active site of the enzyme and previous studies [40, 46, 47], the following assignment is proposed:

$\mathrm{p} K_{\mathrm{e} 2}=5.6: \quad \mathrm{pNPPH}^{-} \rightleftharpoons \mathrm{pNPP}^{2-}+\mathrm{H}^{+}$,

$\mathrm{p} K_{\mathrm{es} 1}=4.9: \quad \mu-\mathrm{OH}^{-} \rightleftharpoons \mu-\mathrm{O}^{2-}+\mathrm{H}^{+}$.

The assignment of $\mathrm{p} K_{\mathrm{e} 2}$ to the deprotonation of the substrate (pNPP) suggests a preferential binding of the substrate in its monoanionic form, while assigning $\mathrm{p} K_{\mathrm{es} 1}$ to the bridging hydroxide supports a role for this ligand as a reaction-initiating nucleophile. Alternatively, $\mathrm{p} K_{\mathrm{es} 1}$ could be assigned to the deprotonation of a terminal Fe(III)bound water molecule. However, the absence of this water ligand in resting Uf [13] make this assignment less likely. Also, the significant change of $\mathrm{p} K_{\mathrm{es} 1}$ upon replacing $\mathrm{Fe}(\mathrm{II})$ 
by $\mathrm{Ni}(\mathrm{II})$ (Table 4 ) indicates that the corresponding ligand is coordinated to the divalent metal ion.

Synthesis and X-ray crystal structure of binuclear $\mathrm{Fe}(\mathrm{III}) \mathrm{Ni}(\mathrm{II})$ biomimetics of Uf

Reaction between $1 \mathrm{mmol}$ of $\mathrm{H}_{2}$ bpbpmp and $1 \mathrm{mmol}$ of $\mathrm{Ni}\left(\mathrm{ClO}_{4}\right)_{2} \cdot 6 \mathrm{H}_{2} \mathrm{O}$ in methanol followed by addition of $1 \mathrm{mmol}$ of $\mathrm{Fe}\left(\mathrm{ClO}_{4}\right)_{3} \cdot 9 \mathrm{H}_{2} \mathrm{O}$ and $2 \mathrm{mmol}$ of sodium acetate results in the formation of $\left[\mathrm{FeNi}(\mathrm{bpbpmp})(\mu \text {-OAc })_{2}\right]\left(\mathrm{ClO}_{4}\right)$ (1), a compound in which the cation is isostructural with similar heterodinuclear mixed-valence $\left[\mathrm{Fe}^{\mathrm{III}} \mathrm{M}^{\mathrm{II}}\right.$ (bpbpmp) $\left.(\mu \text {-OAc })_{2}\right]^{+}\left(\mathrm{M}^{\mathrm{II}}\right.$ is $\left.\mathrm{Zn}, \mathrm{Cu}\right)$ complexes [26, 27]. In the presence of only $1 \mathrm{mmol}$ of sodium acetate the mono $\mu$-OAc complex $\left[\mathrm{Fe}(\mathrm{III}) \mathrm{Ni}(\mathrm{II})(\mathrm{bpbpmp})(\mu\right.$-OAc $\left.)\left(\mathrm{H}_{2} \mathrm{O}\right)_{2}\right]$ $\left(\mathrm{ClO}_{4}\right)_{2} \cdot 2 \mathrm{H}_{2} \mathrm{O}(2)$ is obtained. Stoichiometric reaction of $\mathrm{H}_{2}$ bpbpmp, $\mathrm{Ni}\left(\mathrm{ClO}_{4}\right)_{2} \cdot 6 \mathrm{H}_{2} \mathrm{O}$ and $\mathrm{Fe}\left(\mathrm{ClO}_{4}\right)_{3} \cdot 9 \mathrm{H}_{2} \mathrm{O}$ in methanol, in the presence of perchlorate anion, results in the isolation of $\left[\mathrm{FeNi}(\mathrm{bpbpmp})(\mathrm{OH})\left(\mathrm{H}_{2} \mathrm{O}\right)_{3}\right]\left(\mathrm{ClO}_{4}\right)_{2} \cdot 3 \mathrm{H}_{2} \mathrm{O}$ (3).

The X-ray structure of 2 (Fig. 4) shows that the Ni(II) ion is coordinated to bpbpmp ${ }^{2-}$ through one amine (N4) and two pyridine (N42 and N52) donors. The Fe(III) ion is coordinated through the tertiary amine (N1) and pyridine (N32) and to the oxygen atom of the deprotonated terminal phenol. One exogenous acetate and one endogenous phenoxo group bridge the two metal ions. The distorted octahedral coordination sphere around the $\mathrm{Fe}$ (III) and $\mathrm{Ni}$ (II) centers is completed with one water molecule bound to each metal ion. The structure of $\mathbf{2}$ therefore represents a good functional model for metallophosphatases, since one of the acetate bridges in $\mathbf{1}$ (Fig. 4) is substituted by the coordination of two water molecules.

The Fe(III)-Ni(II) distance in 2 is 3.5166(11) $\AA$, similar to that found for $\left[\mathrm{Fe}(\mathrm{III}) \mathrm{Zn}(\mathrm{II})(\mathrm{bpbpmp})(\mu-\mathrm{OAc})_{2}\right]^{2+}$

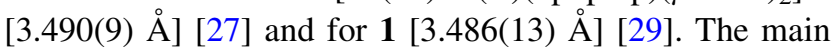
structural difference between $\mathbf{1}$ and $\mathbf{2}$ lies in the mode of the coordination of the tridentate $\mathrm{N}_{2} \mathrm{O}$ pendant arm of bpbpmp ${ }^{2-}$ to the $\mathrm{Fe}(\mathrm{III})$ center. In $\mathbf{1}$ this group is facially bound to $\mathrm{Fe}(\mathrm{III})$, but is meridionally bound in $\mathbf{2}$. Consequently, in $\mathbf{2}$ the terminal $\mathrm{Fe}$ (III)-bound phenoxo group is in a trans position to the pyridine nitrogen atom [Fe-N32 distance is 2.124(7) $\AA$ ], whereas in $\mathbf{1}$ this group is in a trans position to the oxygen atom from the phenoxo bridge [Fe1-O distance is $1.995(3) \AA$ ] . Nevertheless, this change results in only a slight decrease in the bond length Fe-O20 [1.902(3) ̊] for 2 compared with 1 [1.905(3) $\AA$ ], consistent with a greater Lewis acidity of the $\mathrm{Fe}$ (III) center in the former. A water molecule in a trans position to the phenoxo bridge completes the coordination sphere of the Fe(III) center.

The $\mathrm{Fe}-\mathrm{O}_{\text {phenoxo }}-\mathrm{Ni}$ angle $\left[119.17(15)^{\circ}\right]$ in $\mathbf{2}$ is similar to that found in $\mathbf{1}\left[118.66(15)^{\circ}\right]$ and slightly greater than that found for $\left[\mathrm{Fe}(\mathrm{III}) \mathrm{Ni}(\mathrm{II})(\mathrm{BPMP})(\mathrm{OPr})_{2}\right]^{2+}\left[116.2(2)^{\circ}\right]$, where BPMP is the anion of 2,6-bis[(bis(2-pyridylmethyl) amino)methyl]-4-methylphenol [50]. The distances between the metal centers and the phenoxo bridge are also only slightly different in 2 [Fe1-O1 distance 1.982(3) $\AA$ and Ni1-O1 distance 2.095(13) $\AA$ ] and in 1 [Fe1-O distance

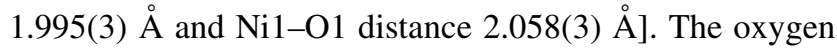
acetate atoms are unsymmetrically coordinated to metal centers in 2 [Fe1-O61 distance 1.973(3) §; Ni1-O62 distance 2.074(3) ̊]].

The X-ray structure of complex 3 (Fig. 4) shows that the ligand is coordinated to the $\mathrm{Ni}$ (II) center in a facial mode and meridionally to the Fe(III). There is no acetate bridge and the metal ions are bound only to the phenoxo bridge from the bpbpmp ${ }^{2-}$ ligand. The $\mathrm{Ni}$ (II) is coordinated to two pyridines and a tertiary amine, and the $\mathrm{N}_{3} \mathrm{O}_{3}$ coordination sphere is completed by two water molecules and the phenoxo bridge. The $\mathrm{Fe}(\mathrm{III})$ center is in an $\mathrm{N}_{2} \mathrm{O}_{4}$ coordination
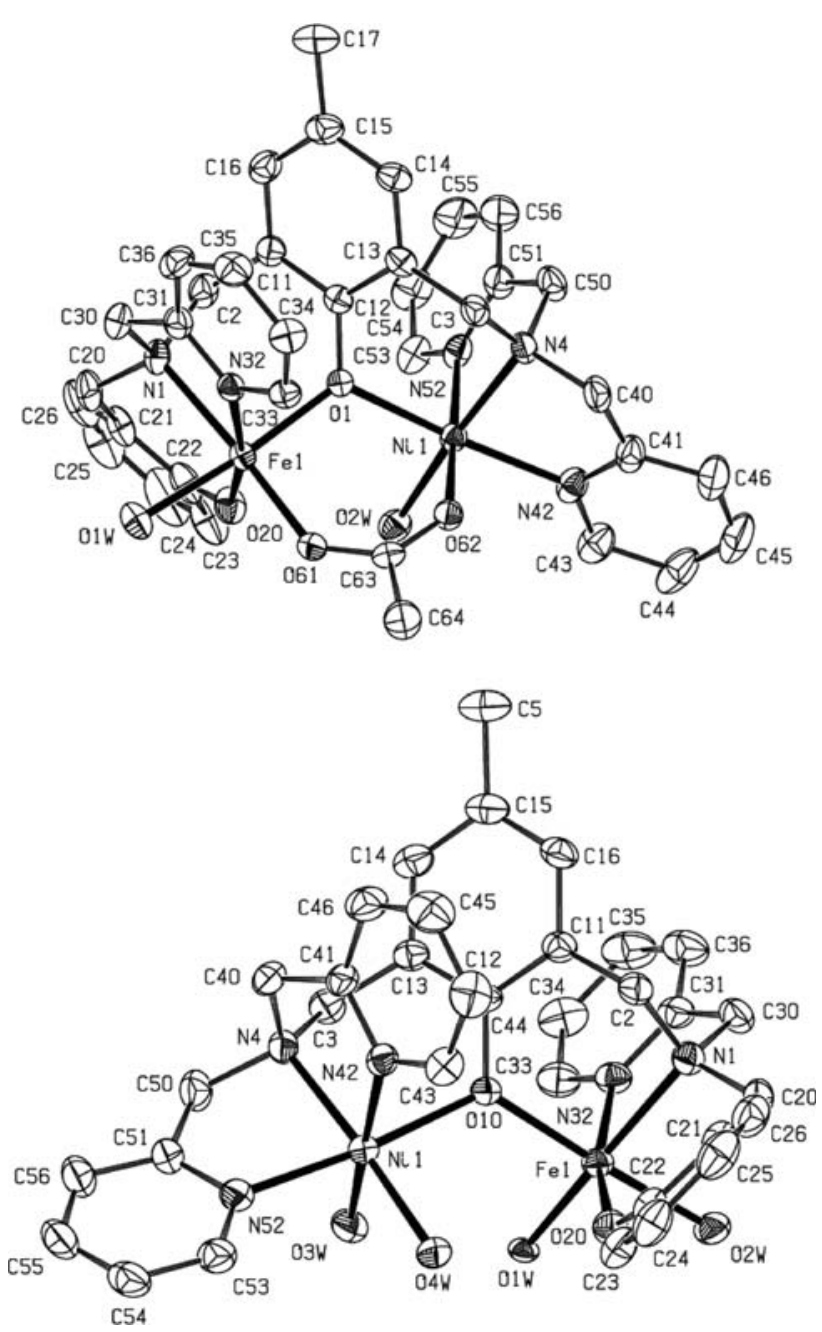

Fig. 4 Top: Crystal structure of $[\mathrm{Fe}(\mathrm{III}) \mathrm{Ni}(\mathrm{II})(\mathrm{bpbpmp})(\mu$ $\left.\mathrm{OAc})\left(\mathrm{H}_{2} \mathrm{O}\right)_{2}\right](\mathrm{ClO} 4)_{2} \cdot 2 \mathrm{H}_{2} \mathrm{O}$ (2). Bottom: Crystal structure of $\left[\mathrm{FeNi}(\mathrm{bpbpmp})(\mathrm{OH})\left(\mathrm{H}_{2} \mathrm{O}\right)_{3}\right]\left(\mathrm{ClO}_{4}\right)_{2} \cdot 3 \mathrm{H}_{2} \mathrm{O}(\mathbf{3})$ 
environment composed of a pyridine and an amine nitrogen atom (N32 and $\mathrm{N} 1$, respectively) and a terminal phenoxo group (O20); the other coordination positions are occupied by a water molecule and a hydroxo group. Completing the heterodinuclear coordination sphere is the phenoxo oxygen originating from the $\mathrm{bpbmp}^{2-}$ ligand, forming a bridge between the two distorted octahedral metal centers. The terminal hydroxo group is strongly bound to the Fe(III) center [Fe(III)-O distance 1.916(3) ̊]. There is considerable asymmetry in $\mathbf{3}$, not only owing to the different coordination spheres around the two centers but also owing to the asymmetric arrangement of the phenoxo bridge with $\mathrm{Fe}(\mathrm{III})-\mathrm{O}_{\text {phenoxo }}[2.007(3) \AA]$ and $\mathrm{Ni}(\mathrm{II})-\mathrm{O}_{\text {phenoxo }}$ [2.161(3) $\AA$ ]. The $\mathrm{Fe}(\mathrm{III})-\mathrm{Ni}(\mathrm{II})$ bond distance is 3.6838(14) $\AA$,

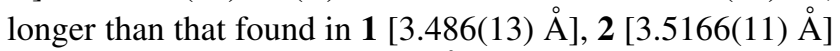
and PAPs (approximately $3.3 \AA[2,14,45,48]$ ). The distance is comparable to those found for $\left[\mathrm{Fe}_{2}(\mathrm{bpbp})\right.$ $\left.(\mathrm{F})_{2}\left(\mathrm{H}_{2} \mathrm{O}\right)\right]\left(\mathrm{BF}_{4}\right)[3.726(2) \AA]$ and $\left[\mathrm{FeCu}(\mathrm{bpbp})(\mathrm{F})_{2}\left(\mathrm{H}_{2} \mathrm{O}\right)\right]$ $\left(\mathrm{BF}_{4}\right)$ [3.828(1) $\left.\mathrm{A}\right]$, where Hbpbp is 2,6-bis $\{$ bis(2-pyridylmethyl)aminomethyl\}-4-tert-butylphenol [51, 52]. The terminal $\mathrm{Fe}-\mathrm{O}_{\text {phenolate }}$ distance $[1.911(3) \AA]$ in $\mathbf{3}$ is similar

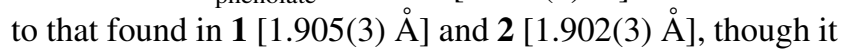
is significantly smaller than the value found for red kidney bean PAP ( $\mathrm{Fe}-\mathrm{O}_{\text {phenolate }}$ distance $2.05 \AA$ ) [48].

The $\mathrm{Fe}-\mathrm{O}_{\text {phenoxo }}-\mathrm{Ni}$ angle in $\mathbf{3}$ is $124.20(14)^{\circ}$, greater than those found for $1\left[118.66(15)^{\circ}\right]$ and $2\left[119.17(15)^{\circ}\right]$; however, it is similar to those found in other heterovalent compounds $\left[\mathrm{Fe}_{2}(\mathrm{bpbp})(\mathrm{F})_{2}\left(\mathrm{H}_{2} \mathrm{O}\right)\right]\left(\mathrm{BF}_{4}\right) \quad\left[124.6(3)^{\circ}\right]$ and $\left[\mathrm{FeCu}(\mathrm{bpbp})(\mathrm{F})_{2}\left(\mathrm{H}_{2} \mathrm{O}\right)\right]\left(\mathrm{BF}_{4}\right)\left[126.72(10)^{\circ}\right]$ that contain a fluoride ion, considered isoelectronic to the hydroxo ion $[51,52]$.

The most significant characteristic of this structure is the presence of a hydroxo group coordinated to the Fe(III) center in a cis position to a water molecule coordinated to the Ni(II) center. The presence of a nucleophile group, such as a hydroxo, is an important factor in studying the activity of these compounds in the hydrolysis of phosphate esters or diesters. These features lead to $\mathbf{3}$ being a very good structural model, and possibly a functional model, for PAPs and related metallohydrolases.

Magnetic susceptibility of $\mathrm{Fe}(\mathrm{III}) \mathrm{Ni}(\mathrm{II})$ biomimetics of Uf

The magnetic properties of complexes $\mathbf{1}, \mathbf{2}$ and $\mathbf{3}$ are reported in the form of $\chi_{\mathrm{M}} T$ versus $T$ plots in a field of $1 \mathrm{~T}$ for the three complexes (Figs. 5, S1). In each case at $300 \mathrm{~K}$ the moment (approximately $6.20 \mu_{\mathrm{B}}$ ) is lower than expected for uncoupled $\mathrm{Fe}(\mathrm{III}) \mathrm{Ni}(\mathrm{II}) \quad(S=5 / 2 ; S=1)$ ions $\left(g_{\mathrm{av}}=2.0\right)$. The $\mu_{\mathrm{eff}}$ values uniformly decrease from $300 \mathrm{~K}$, reaching $3.66 \mu_{\mathrm{B}}$ at $2 \mathrm{~K}$ indicative of antiferromagnetic coupling and a ground state with $S=3 / 2$ for the systems. Analysis of the data for the complexes was based on the Hamiltonian $H=-2 J S_{1} \cdot S_{2}$ using previously reported procedures taking into account the contributions of the individual $g_{\mathrm{Fe}}$ and $g_{\mathrm{Ni}}$ values [53, 54]. The exchange coupling constants are of similar magnitude in the three complexes (for $3, J=-13.7 \mathrm{~cm}^{-1}, g_{\mathrm{Fe}}=1.98$ and $g_{\mathrm{Ni}}=$ $2.11 ; R=3.7454 \times 10^{-4}$; Table 4$)$. $R$, the function minimized in the curve fitting, was $R=\Sigma\left(\chi_{\mathrm{m}}^{\mathrm{obs}}-\chi_{\mathrm{m}}^{\mathrm{calc}}\right)^{2} /$ $\Sigma\left(\chi_{\mathrm{m}}^{\mathrm{obs}}\right)^{2}$. The magnitude of the antiferromagnetic coupling is comparable to that determined for the complex [Fe(III) $\left.\mathrm{Ni}(\mathrm{II})(\mathrm{BPMP})(\mathrm{OPr})_{2}\right]\left(\mathrm{BPh}_{4}\right)_{2}\left(J=-12.5 \mathrm{~cm}^{-1}\right)$ [50]. The data suggest that the major pathway for exchange coupling is mediated via the phenoxide bridge and that the acetate groups have very little effect on the magnetic properties of the binuclear center. The magnitude of $|J|$ for $\mathbf{2}$ and $\mathbf{3}$ is consistent with the crystal structure (Fig. 4) showing the presence of only one oxo bridge, from the phenoxide, and the absence of $\mu-\mathrm{O}^{2-}$ or $\mu-\mathrm{OH}^{-}$.

Electronic absorption spectroscopy and MCD of $\mathrm{Fe}(\mathrm{III}) \mathrm{Ni}(\mathrm{II})$ biomimetics of Uf

Electronic spectra of $\mathbf{1 ,} \mathbf{2}$ and $\mathbf{3}$, dissolved in acetonitrile, are shown in Fig. 6 and data are given in Table 4. The broad feature between 520 and $560 \mathrm{~nm}$ is attributed to the terminal phenolate to Fe(III) LMCT transition, characteristic of isostructural model complexes [24-31] and PAPs [1, 2, 10-12]. The $\lambda_{\max }$ (and corresponding extinction coefficients) for $\mathbf{1}, \mathbf{2}$ and $\mathbf{3}$ (Tables 4 and S1) are similar to those determined for both related model complexes and

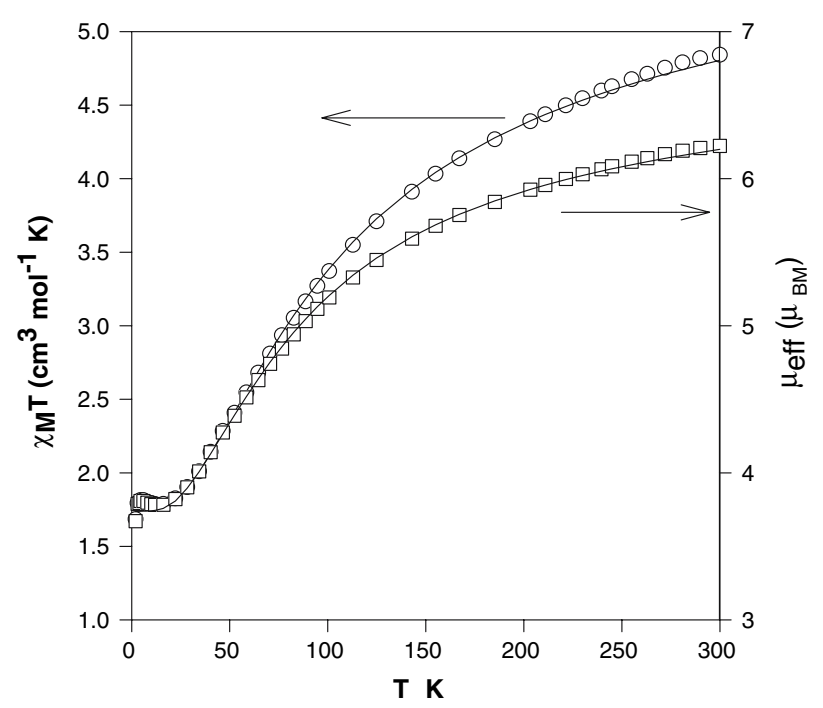

Fig. $5 \chi_{\mathrm{M}} T$ versus $T$ for 2 . The data were fitted with a Van Vleck expression derived for an $S_{\mathrm{Fe}}=5 / 2, S_{\mathrm{Ni}}=1$ system and including no zero-field-splitting-fitting term. While this approach may not accommodate variations at very low temperatures it does allow determination of the magnitude and sign of $J$ [53] 
Fig. 6 The room-temperature absorption (lower) and lowtemperature magnetic circular dichroism (MCD; upper) spectra of a $[\mathrm{FeNi}(\mathrm{bpbpmp})(\mu$ $\left.\mathrm{OAc})_{2}\right]\left(\mathrm{ClO}_{4}\right)(\mathbf{1})(\mathbf{a}), 2$ (b) and 3 (c). Gaussian resolution was made simultaneously on MCD and absorption spectra. Absorption spectra were measured in acetonitrile, while MCD samples were in a methanol/ethanol glass at $4.2 \mathrm{~K}$, 5 T. Additional transitions associated with the charge transfer band are anticipated in the high-energy region (approximately $30,000 \mathrm{~cm}^{-1}$ ) [12] but were not observed owing to instrumental limitations
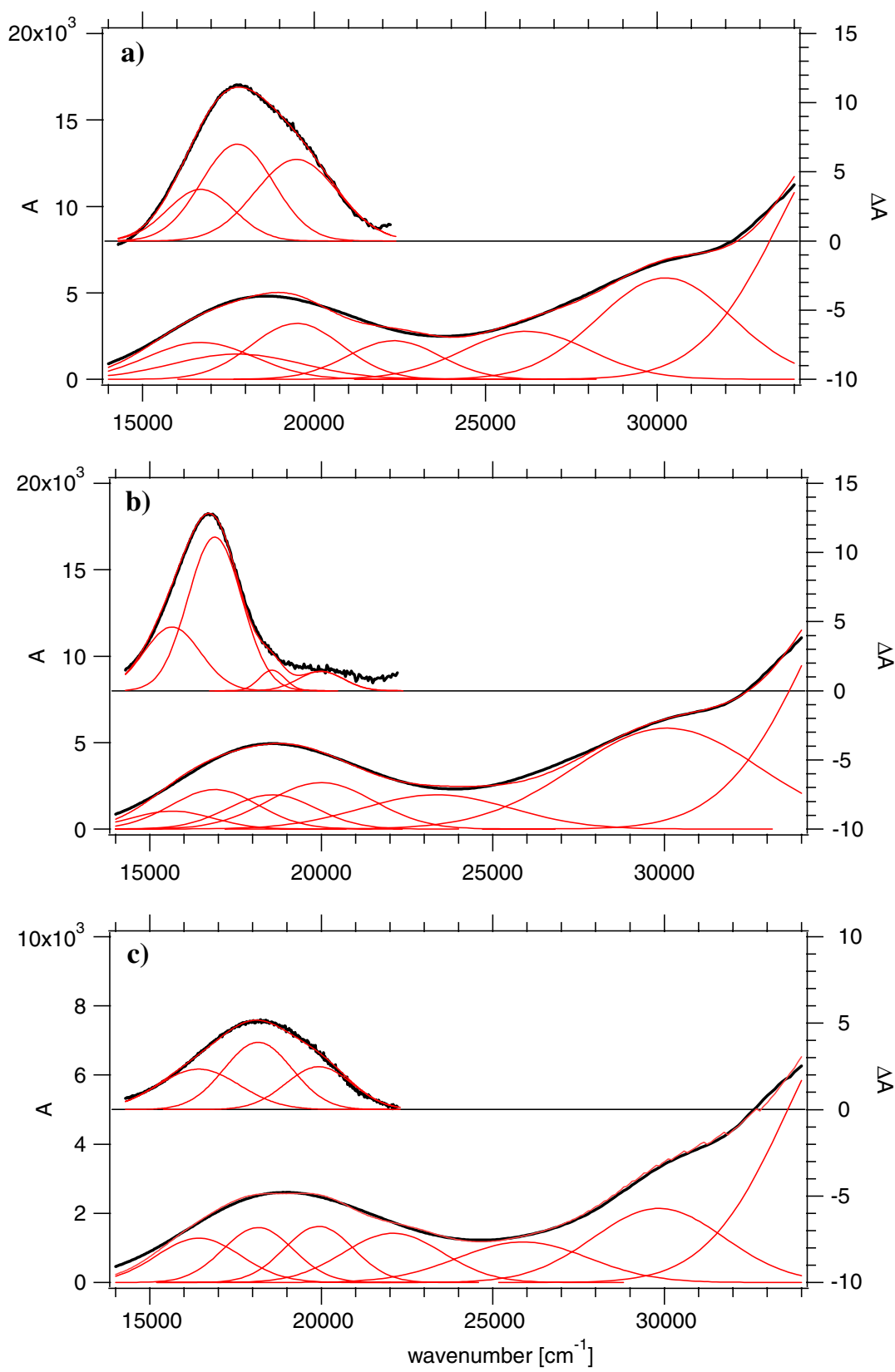

PAPs. Hence, the model complexes can be considered as good synthetic analogs for the chromophoric site of the protein systems. The observed increase in energy for the LMCT transition in $\mathbf{3}$ indicates a reduction in the effective nuclear charge of the ferric ion with a concomitant increase in the energy of the $d$ orbitals [12]. Furthermore, the lower intensity of this transition in $\mathbf{3}$ is also consistent with a weakening of the bond between the terminal phenolate ligand and $\mathrm{Fe}(\mathrm{III})$. Finally, a weak band observed at approximately $930 \mathrm{~nm}$ in all three complexes is ascribed to a Ni(II) ${ }^{3} \mathrm{~A}_{2 \mathrm{~g}} \rightarrow{ }^{3} \mathrm{~T}_{2 \mathrm{~g}} d \rightarrow d$ transition (data not shown).

MCD spectra $(450-700 \mathrm{~nm})$ of the three model complexes were recorded at $4.2 \mathrm{~K}$ at a magnetic field of $5 \mathrm{~T}$
(Fig. 6). The observed transitions in this energy region are associated with the charge transfer complex as discussed above. The temperature dependence of the bands at $5 \mathrm{~T}$ was also determined and demonstrated that the main contribution to the signal is the C-term [55-57] as expected for a ground-state Kramers doublet of an odd-electron system. The MCD spectrum of $\mathbf{2}$ is clearly distinct from those of $\mathbf{1}$ and $\mathbf{3}$, with one dominant band and two weaker transitions (Fig. 6). The origin of the difference is not immediately apparent and the MCD of these, and similar complexes, is under further examination. Assuming that the conformations in the X-ray structures are retained in solution, the differences may reflect the unusual position of the terminal 
Fe(III)-bound phenoxo group being cis to the bridging phenoxo in $\mathbf{2}$, rather than trans in the structures of $\mathbf{1}$ and $\mathbf{3}$.

For the complexes the short phenoxy-iron bond defines the axes of the $\mathrm{Fe}(\mathrm{III}) d$ orbitals. There are a total of four electronic transitions expected in this region corresponding to an electron being promoted from the two $\pi$ orbitals localized on the phenolate ligand to the two $t_{2 \mathrm{~g}}$ orbitals, $d_{x z}$ and $d_{y z}$, which participate with $\pi$-bonding to the largest extent and are predicted to have the greatest intensity [12]. These $\pi$ orbitals on the phenolate ligand actually exhibit mixed $\sigma / \pi$ bonding character, depending on the particular orientation of the phenolate plane. Thus, two additional bands, due to the $\pi_{\mathrm{op}}, \pi_{\mathrm{ip}} \rightarrow d_{z^{2}}$ transitions, are also expected at higher energy. The Gaussian resolution of the broad MCD peak requires a minimum of three fitted Gaussian bands. If the Gaussian fit is made simultaneously to both absorption and MCD data sets, common peak positions can be used to reduce the number of parameters to be fitted, while areas and widths are allowed to vary [58]. There are approximations in this modeling approach in using low-temperature MCD and room-temperature absorption spectra. The low-temperature absorption spectra did not show any major differences from the room-temperature spectra, apart from a slight sharpening of the bands. However, there were some baseline and scattering effects in the low-temperature absorption spectra that are inherent in the nature of frozen-glass samples, which makes it preferable to use the room-temperature absorption spectra in the fitting process. In all cases the MCD spectra show the band maxima at lower energy than in the absorption spectrum. Fixing the three peak positions from the MCD, we required a fourth peak in the absorption spectrum. Details of the fit (Table S1) imply that splitting of the $d_{x z}, d_{y z}$ orbitals (of the order $1,000-2,000 \mathrm{~cm}^{-1}$ ) is less than that of the $\pi_{\mathrm{op}}, \pi_{\mathrm{ip}}$ orbitals $\left(2,000-3,000 \mathrm{~cm}^{-1}\right)$. Two additional peaks were fitted to higher energy, one appearing as a shoulder at approximately $30,000 \mathrm{~cm}^{-1}$ and the other at approximately $25,000 \mathrm{~cm}^{-1}$. The weighted average of these two peaks minus that of the four peaks at lower energy is approximately $10,000 \mathrm{~cm}^{-1}$ and corresponds to the effective octahedral splitting of the $e_{\mathrm{g}}$ and $t_{2 \mathrm{~g}}$ orbitals on the $\mathrm{Fe}^{\mathrm{III}}$.

\section{Electrochemistry of $\mathrm{Fe}(\mathrm{III}) \mathrm{Ni}(\mathrm{II})$ biomimetics of Uf}

Electrochemical data for $\mathbf{1}$ [29], 2 and $\mathbf{3}$ and relevant parameters are presented in Table 4 and Fig. S2. Complexes $\mathbf{1}$ and $\mathbf{2}$ reveal quasi-reversible behavior for the $\mathrm{Fe}(\mathrm{III}) \mathrm{Ni}(\mathrm{II}) / \mathrm{Fe}(\mathrm{II}) \mathrm{Ni}$ (II) redox process. The differences between the redox potentials for complexes 1, 2 and $\mathbf{3}$ can be ascribed to the different acidities of the Fe(III) centers in these complexes. The anodic shift of $0.46 \mathrm{~V}$ observed between complexes $\mathbf{1}$ and $\mathbf{2}$ is due to the exchange of one acetate for a water molecule, which lowers the electronic density of the $\mathrm{Fe}$ (III) center. Contrastingly, the presence of the hydroxo group in $\mathbf{3}$ increases the electronic density of the Fe(III) center, thus promoting a cathodic shift when compared with complex 2.

Comparison of the potential of the $\mathrm{Fe}(\mathrm{III}) \mathrm{Ni}(\mathrm{II}) / \mathrm{Fe}(\mathrm{II})-$ $\mathrm{Ni}$ (II) couple in $\mathbf{1}$ with those observed for similar $\left[\mathrm{Fe}(\mathrm{III}) \mathrm{M}(\mathrm{II})(\mathrm{bpbpmp})(\mu \text {-OAc })_{2}\right]^{+}$complexes $[\mathrm{M}(\mathrm{II})$ is $\mathrm{Fe}$, $\mathrm{Mn}$ and $\mathrm{Zn}$; Table 4] shows that only small displacements for this process are observed, in agreement with the common coordination environment around the Fe(III) [24-31]. The voltammograms of $\mathbf{1}, \mathbf{2}$ and $\mathbf{3}$ show one irreversible cathodic wave comparable to the $\mathrm{Ni}$ (II)Ni(II)/ $\mathrm{Ni}(\mathrm{II}) \mathrm{Ni}(\mathrm{I})$ redox process observed in the $\left[\mathrm{Ni}_{2}(\mathrm{II})(\mathrm{Hbpbpmp})(\mu\right.$ $\left.\mathrm{OAc})_{2}\right]^{+}$complex [59] (Table 4), and which is assigned to the $\mathrm{Fe}(\mathrm{II}) \mathrm{Ni}(\mathrm{II}) / \mathrm{Fe}(\mathrm{II}) \mathrm{Ni}(\mathrm{I})$ nickel-centered process. The redox process observed at $E_{1 / 2}=+0.76 \mathrm{~V}$ for $\mathbf{1}$ is anodicshifted by approximately $0.2 \mathrm{~V}$ but is still comparable with the $\mathrm{Ni}$ (III)Ni(II)/Ni(II)Ni(II) redox couple found for the corresponding $\mathrm{Ni}_{2}$ (II) complex $\left(+0.59 \mathrm{~V}\right.$ vs $\left.\mathrm{Fc}^{+} / \mathrm{Fc}\right)$ [59]. Interestingly, this process was not observed for complexes $\mathbf{2}$ and $\mathbf{3}$, most probably because it is anodic-shifted in relation to complex 3 and therefore out of the investigated potential range $(-1.4$ to $+1.4 \mathrm{~V})$.

The $\left[\mathrm{Fe}(\mathrm{III}) \mathrm{Fe}(\mathrm{II})(\mathrm{bpbpmp})(\mathrm{OAc})_{2}\right]^{+}$complex [31] and Uf [3, 4] show similar redox potentials for the Fe(III)$\mathrm{Fe}(\mathrm{III}) / \mathrm{Fe}(\mathrm{III}) \mathrm{Fe}(\mathrm{II})$ redox process, which suggests a similar Lewis acidity of the Fe(II) center in both species. It is proposed that the reversible redox potential at $+0.557 \mathrm{~V}$ for $\mathrm{Fe}(\mathrm{III}) \mathrm{Ni}(\mathrm{II})-\mathrm{Uf}$ is associated with the oxidation of the tyrosinate (Tyr55) ligand involved in the LMCT transition instead of the $\mathrm{Ni}$ (II)/ $\mathrm{Ni}$ (III) oxidation process (vide supra). This proposal is in full agreement with the redox properties of the biomimetic complex 3 , which does not show any redox process in the $0.0-1.0-\mathrm{V}$ (vs NHE) range. Importantly, in biomimetic systems, stable phenoxyl radical complexes with some electrochemical response are normally generated when the bound phenolate ligand is adequately protected by bulky substituents (tert-butyl) [60].

X-ray absorption spectroscopy of $\mathbf{3}$

Iron K-edge EXAFS spectra collected for $\mathbf{3}$ in both solid and dissolved states are shown in Fig. 7. The corresponding fits of the EXAFS data $k^{3} \chi(k)$ and the Fourier transform $\chi(R)$ data are also shown. The metal-metal distance determined from these data is $3.72 \AA$, in good agreement with the crystallographic metal-metal distance of $3.684 \AA$. In a 70:30 acetonitrile/water solution the metal-metal distance determined by EXAFS was found to be $3.73 \AA$, 
Fig. 7 a Solid-state $k^{3} \chi(k)$ and $\chi(R)$ extended X-ray absorption fine structure $(E X A F S)$ data and corresponding fits for $\mathbf{3}$. The metal-metal distance determined from the EXAFS data is $3.719 \AA$, which correlates well with crystallographic data showing a metal-metal distance of $3.684 \AA$ A. b Dissolved-state $k^{3} \chi(k)$ and $\chi(R)$ EXAFS data and corresponding fits for 3 . The metal-metal distance determined $(3.735 \AA)$ is similar to that determined for the solid state, indicating the complex maintains its structural integrity upon dissolution
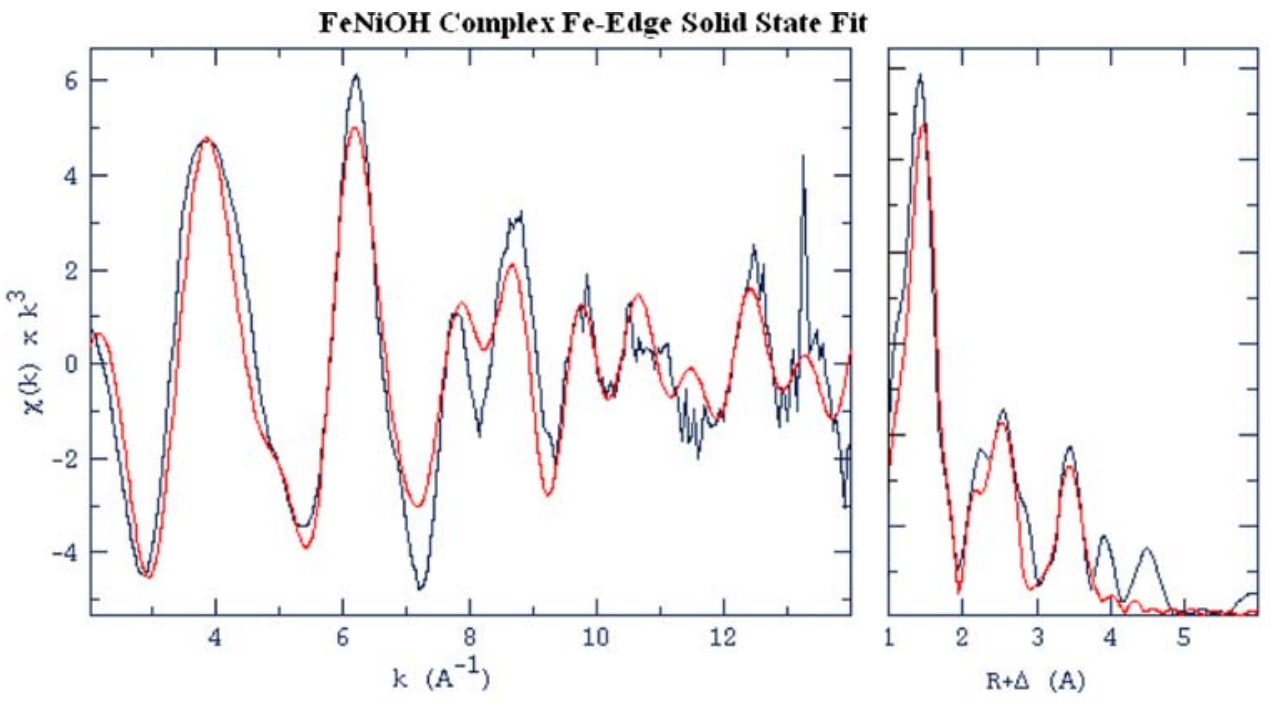

FeNiOH Complex Fe-Edge Solution State EXAFS Fit
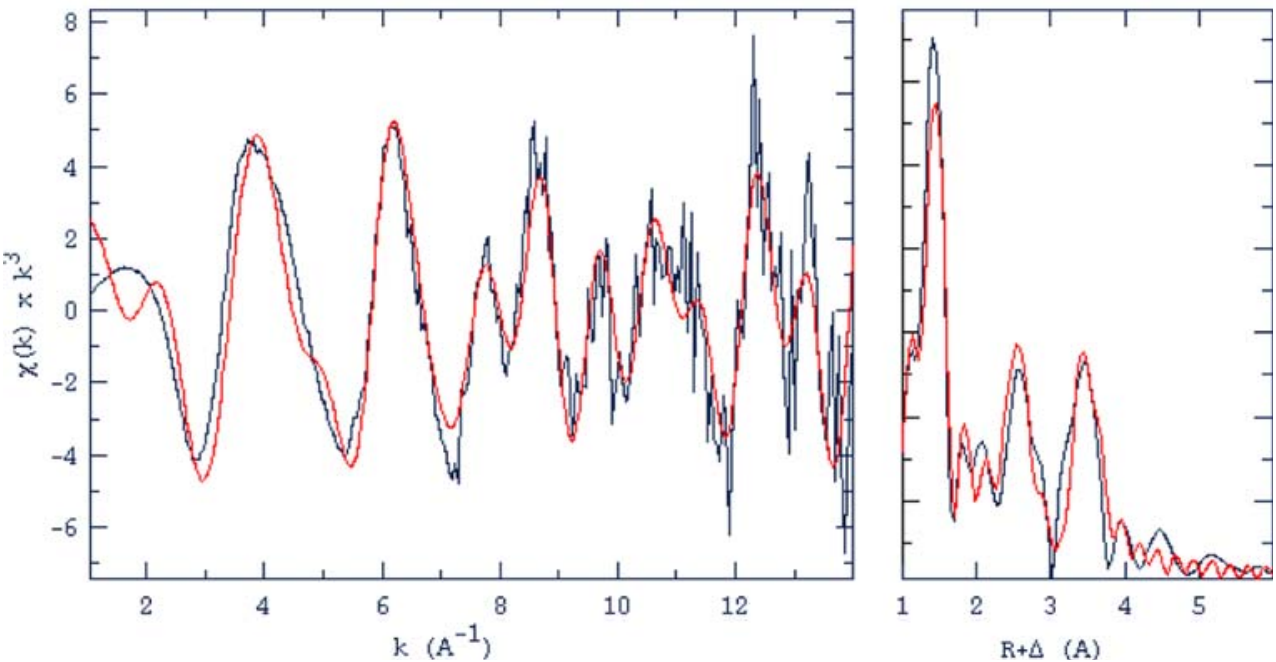

indicating that the overall structure of the binuclear center remains intact in aqueous solution.

Potentiometric equilibrium determination of $\mathrm{Fe}(\mathrm{III}) \mathrm{Ni}(\mathrm{II})$ biomimetics of $\mathrm{Uf}$

Potentiometric titration studies with $\mathbf{2}$ and $\mathbf{3}$ (in a 30:70 water/ethanol solution) showed the neutralization of $3 \mathrm{~mol}$ $\mathrm{KOH} \mathrm{mol}{ }^{-1}$ in the $\mathrm{pH}$ range $4-10$; corresponding $\mathrm{p} K_{\mathrm{a}}$ values are shown in Table 4 (data for $\mathbf{1}$ were determined previously [29]). The release of the acetate group in solution in $\mathbf{1}$ and $\mathbf{2}$ is associated with its lability [27, 61] and promotes the coordination of water molecules to the $\mathrm{Fe}$ (III) center. $\mathrm{p} K_{\mathrm{a} 1}$ and $\mathrm{p} K_{\mathrm{a} 2}$ in $\mathbf{1}$ and $\mathbf{2}$ are attributed to the deprotonation of the water molecules bound to the $\mathrm{Fe}$ (III) center. On the other hand, it is assumed that the coordination environment around the $\mathrm{Fe}(\mathrm{III})$ and $\mathrm{Ni}$ (II) in $\mathbf{3}$ is maintained in aqueous solution since under the experimental conditions only the dinucleating ligand and $\mathrm{H}_{2} \mathrm{O}$ / $\mathrm{OH}^{-}$molecules occupy the first coordination sphere of the $\mathrm{Fe}(\mathrm{III})$ and $\mathrm{Ni}$ (II) centers. This proposal is in full agreement with the EXAFS data in solution which reveal that the $\mathrm{Fe} \cdot \mathrm{Ni}$ distance of approximately $3.7 \AA$ obtained from the $\mathrm{X}$-ray structure of $\mathbf{3}$ is maintained when the complex is dissolved in acetronitile/water (Fig. 7). Therefore, we propose the equilibria shown in Scheme 2.

Deprotonation of the Fe(III)-bound water molecule $\left(\mathrm{p} K_{\mathrm{a} 1}=4.30\right)$ in a cis position to a water molecule coordinated to the $\mathrm{Ni}$ (II) center is anticipated on the basis of the structure of $\mathbf{3}$, which reveals that this coordination position is occupied by a hydroxide ligand. $\mathrm{p} K_{\mathrm{a}}$ values at 4.90 and 8.10 found for 3 are assigned to deprotonation of the second $\mathrm{Fe}-\mathrm{H}_{2} \mathrm{O}$ molecule and to deprotonation of one of the $\mathrm{Ni}(\mathrm{II})-\mathrm{H}_{2} \mathrm{O}$ molecules, respectively. Interestingly, the $\mathrm{p} K_{\mathrm{a}}$ of 4.80 determined for $\mathbf{2}$ compares favorably with the 

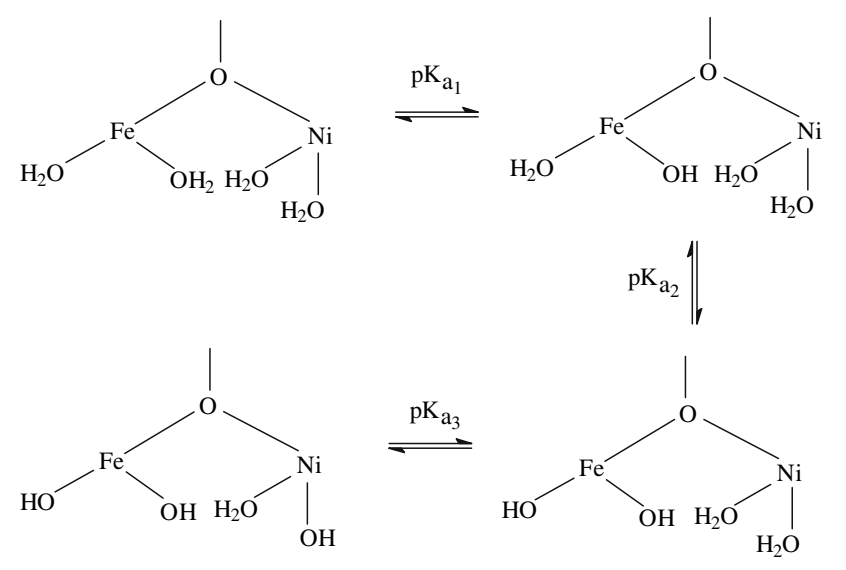

Scheme 2 Proposed equilibria for biomimetics 1-3

second $\mathrm{p} K_{\mathrm{a}}$ of 4.90 found for $\mathbf{3}$, indicating that this deprotonation/protonation process is most probably related to the water molecule which is in a trans position to the bridging phenolate in both complexes. The $\mathrm{p} K_{\mathrm{a} 1}$ of 5.30 determined for $\mathbf{1}$ is approximately $0.5 \mathrm{pH}$ units higher than the values found for $\mathbf{2}$ and $\mathbf{3}$.

Phosphatase-like activity of $\mathrm{Fe}(\mathrm{III}) \mathrm{Ni}(\mathrm{II})$ biomimetics of Uf

The phosphatase-like activity of the three model systems was measured under conditions of excess substrate, using the activated substrate 2,4-bdNPP. Complexes 1, 2 and $\mathbf{3}$ possess the following important kinetic features: (1) labile sites-carboxylate bridge(s) in $\mathbf{1}$ and $\mathbf{2}$; (2) water molecules coordinated to the $\mathrm{Fe}(\mathrm{III})$ and $\mathrm{Ni}(\mathrm{II})$ centerscomplexes $\mathbf{2}$ and $\mathbf{3}$; (3) the presence of a hydroxo group coordinated to the $\mathrm{Fe}(\mathrm{III})$ center-complex 3 ; (4) low $\mathrm{p} K_{\mathrm{a}}$ values for one of the water molecules coordinated to the Fe(III) center, generating a good nucleophile. This last characteristic is present in all three complexes, as can be observed in the $\mathrm{p} K_{\mathrm{a}}$ values obtained (Table 4) and the $\mathrm{pH}$ of optimal activity observed for the hydrolysis of the diester substrate 2,4-bdNPP.

The catalytic activity of the three model systems was investigated in the $\mathrm{pH}$ range 3.0-9.0 (Fig. S3). The $\mathrm{pH}$ values for optimal activity are 6.0, 6.5 and 6.0 for complexes 1 [29], 2 and 3, respectively, in agreement with those found for similar complexes [25-31] and for PAPs [2, 6, 8, 14, 40, 42, 46, 49]. Using Eq. 1, we determined $\mathrm{p} K_{\mathrm{es} 1}$ values of $4.9,4.9$ and 5.1 and $\mathrm{p} K_{\mathrm{es} 2}$ values of 8.3, 7.8 and 7.5 for $\mathbf{1}, \mathbf{2}$ and 3, respectively. For 1 and $2 \mathrm{p} K_{\mathrm{es} 1}$ and $\mathrm{p} K_{\mathrm{es} 2}$ are in good agreement with $\mathrm{p} K_{\mathrm{a} 1}$ and $\mathrm{p} K_{\mathrm{a} 3}$ obtained from the potentiometric titrations (Table 4). In contrast, for $3, \mathrm{p} K_{\mathrm{es} 1}$ and $\mathrm{p} K_{\mathrm{es} 2}$ are comparable with $\mathrm{p} K_{\mathrm{a} 2}$ and $\mathrm{p} K_{\mathrm{a} 3}$. This difference may be associated with the substitution of the water molecule at the Fe(III) site in 3 by 2,4-bdNPP. This substitution is expected to provoke an increase in the electronic density on Fe(III), lowering its Lewis acidity and raising the $\mathrm{p} K_{\mathrm{a}}$ of the hydroxo group coordinated to this metal site.

The dependence of the initial rates, at optimal $\mathrm{pH}$, on the concentration of the substrate reveals saturation kinetics with Michaelis-Menten-like behavior [44] (Fig. S4). The resulting $k_{\text {cat }}$ and $K_{\mathrm{M}}$ are listed in Table 4 . The reactions catalyzed by the three systems are likely to be initiated by the terminal hydroxo group coordinated to the $\mathrm{Fe}$ (III) center. The lower activity of $\mathbf{1}$ compared with $\mathbf{2}$ and $\mathbf{3}$ may be related, at least in part, to the competitive inhibition due to the acetate bridge in solution, and/or to structural differences of the active species when the complexes are dissolved. The reactivities of $\mathbf{2}$ and $\mathbf{3}$ are similar and indicate that the catalytically relevant species of these two complexes, in solution, are likely to exhibit similar geometries and ligand coordination.

\section{Conclusions}

The data presented for the Fe(III)Ni(II) derivative of Uf supports a mechanistic model whereby initial binding of the substrate is followed by a nucleophilic attack by a metal ion bridging (hydr)oxide (Scheme 1). This mechanistic scheme is similar to that proposed for the $\mathrm{Fe}(\mathrm{III}) \mathrm{Mn}$ (II) sweet potato PAP [2, 9, 14] and the $\mathrm{Ga}$ (III)Zn(II) derivative of Uf [15], but is in contrast to that reported for the $\mathrm{Fe}$ (III)Fe(II) and $\mathrm{Fe}$ (III)Zn(II) forms of Uf and the Fe(III)Zn(II) red kidney bean PAP [15, 48, 49], which employs a terminal, Fe(III)-bound hydroxide as a nucleophile. From a comparison of experimental data for various derivatives of Uf it emerges thus that the metal ion composition may influence the precise catalytic strategy employed by the enyzme to hydrolyze ester bonds. Both the terminal, Fe(III)-bound and the metal ion bridging hydroxides can act as reaction-initiating nucleophiles depending on the metal ion composition. Structural changes in the active site of Uf induced by different coordination geometry preferences for different metal ions are likely to be the cause for these mechanistic variations. This hypothesis is further supported by the recent observation that Uf is able to hydrolyze, in sequence, both ester bonds of the diester substrate methyl-pNPP [16]; the terminal hydroxide initiates hydrolysis of the first ester bond, while the bridging hydroxide initiates cleavage of the second bond.

The isostructural Fe(III)M(II) biomimetics presented here and elsewhere [24-31] provide good structural, but also reasonable functional models for both types of enzymatic mechanisms. In contrast to $\mathrm{Fe}(\mathrm{III}) \mathrm{Ni}(\mathrm{II})-\mathrm{Uf}$, the 


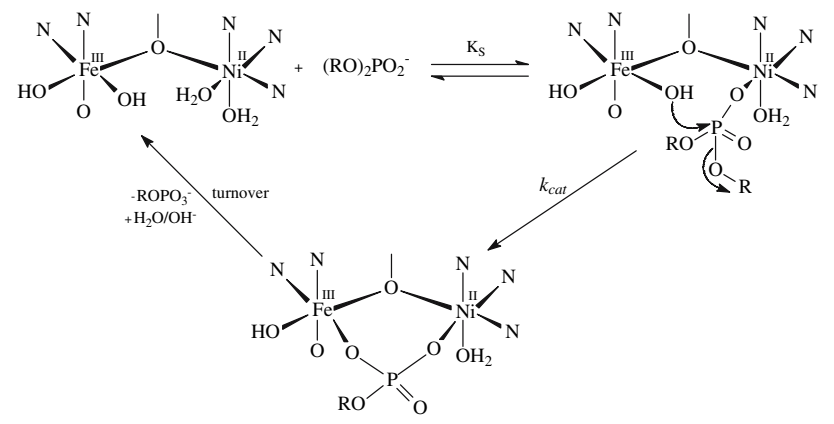

Scheme 3 Proposed mechanism for PAP biomimetics with $\mathrm{Fe}(\mathrm{III})$ $\mathrm{Ni}(\mathrm{II})$ and $\mathrm{Fe}(\mathrm{III}) \mathrm{Zn}(\mathrm{II})$ binuclear metal centers

three FeNi models described in this study employ a terminal $\mathrm{Fe}(\mathrm{III})$-bound hydroxide as a nucleophile (Scheme 3), similar to the isostructural $\mathrm{Fe}(\mathrm{III}) \mathrm{Zn}$ (II) complex [28]. Thus, metal ion composition does not seem to be the only factor affecting the mechanism of hydrolysis. The specific comparison between the $\mathrm{Ni}(\mathrm{II})$-containing derivatives of Uf and biomimetics illustrates that identical metal composition does not lead to the same mechanism, an observation which highlights the significance of the dynamic ligand environment in the protein active site for the optimization of the catalytic efficiency.

Acknowledgments This work was funded by a grant from the Australian Research Council (DP0558652) and CNPq, FAPESC from Brazil. X-ray absorption data collection was performed at the Australian National Beamline Facility (ANBF), Tsukuba, Japan, with support from the Australian Synchrotron Research Program, funded by the Commonwealth of Australia under the Major National Research Facilities Program. We also thank G. Foran for help in data collection. The guidance of Paul Bernhardt in electrochemical measurements with Uf and the assistance of Keith Murray (Monash University, VIC, Australia) with collection of the susceptibility data are kindly acknowledged.

\section{References}

1. Wilcox DE (1996) Chem Rev 96:2435-2458

2. Mitić N, Smith SJ, Neves A, Guddat LW, Gahan LR, Schenk G (2006) Chem Rev 106:3338-3363

3. Bernhardt PV, Schenk G, Wilson GJ (2004) Biochemistry 43:10387-10392

4. Wang DL, Holz RC, David SS, Que L, Stankovich MT (1991) Biochemistry 30:8187-8194

5. Schenk G, Guddat LW, Ge Y, Carrington LE, Hume DA, Hamilton S, de Jersey J (2000) Gene 250:117-125

6. Beck JL, McConachie LA, Summors AC, Arnold WN, de Jersey J, Zerner B (1986) Biochim Biophys Acta 869:61-68

7. Schenk G, Ge Y, Carrington LE, Wynne CJ, Searle IR, Carroll BJ, Hamilton S, de Jersey J (1999) Arch Biochem Biophys 370:183-189

8. Durmus A, Eicken C, Sift BH, Kratel A, Kappi R, Hütterman J, Krebs B (1999) Eur J Biochem 260:709-716

9. Schenk G, Boutchard CL, Carrington LE, Noble CJ, Moubaraki B, Murray KS, de Jersey J, Hanson GR, Hamilton S (2001) J Biol Chem 276:19084-19088
10. Antanaitis BC, Aisen P, Lilienthal HR (1983) J Biol Chem 258:3166-3172

11. Averill BA, Davis JC, Burman S, Zirino T, Sanders-Loehr J, Loehr TM, Sage JT, Debrunner PG (1987) J Am Chem Soc 109:3760-3767

12. Yang Y-S, McCormick JM, Solomon EI (1997) J Am Chem Soc 119:11832-11842

13. Smoukov SK, Quaroni L, Wang X, Doan PE, Hoffman BM, Que L Jr (2002) J Am Chem Soc 124:2595-2603

14. Schenk G, Gahan LR, Carrington LE, Mitić N, Valizadeh M, Hamilton SE, de Jersey J, Guddat LW (2005) Proc Natl Acad Sci USA 102:273-278

15. Smith SJ, Casellato A, Hadler KS, Mitić N, Riley MJ, Bortoluzzi AJ, Szpoganicz B, Schenk G, Neves A, Gahan LR (2007) J Biol Inorg Chem (in press)

16. Cox RS, Schenk G, Mitić N, Gahan LR, Hengge AC (2007) J Am Chem Soc 129:9550-9551

17. Elliott TW, Mitić N, Gahan LR, Guddat LW, Schenk G (2006) J Braz Chem Soc 17:1558-1565

18. Funhoff EG, Klaasen CHW, Samyn B, Van Beeumen J, Averill BA (2001) Chembiochem 2:355-363

19. Mitić N, Valizadeh M, Leung EWW, de Jersey J, Hamilton S, Hume DA, Cassady AI, Schenk G (2005) Arch Biochem Biophys 439:154-464

20. Beck JL, Keough DT, de Jersey J, Zerner B (1984) Biochim Biophys Acta 791:357-363

21. Beck JL, Durack MCA, Hamilton SE, de Jersey J (1999) J Inorg Biochem 73:245-252

22. Beck JL, de Jersey J, Zerner B, Hendrich MP, Debrunner PG (1988) J Am Chem Soc 110:3317-3318

23. Beck JL, McArthur MJ, de Jersey J, Zerner B (1988) Inorg Chim Acta 153:39-44

24. Neves A, de Brito MA, Vencato I, Drago V, Griesar K, Haase W (1996) Inorg Chem 35:2360-2368

25. Karsten P, Neves A, Bortoluzzi AJ, Lanznaster M, Drago V (2002) Inorg Chem 41:4624-4626

26. Lanznaster M, Neves A, Bortoluzzi AJ, Aires VVE, Szpoganicz B, Terenzi H, Severino PC, Fuller JM, Drew SC, Gahan LR, Hanson GR, Riley MJ, Schenk G (2005) J Biol Inorg Chem 10:319-332

27. Lanznaster M, Neves A, Bortoluzzi AJ, Szpoganicz B, Schwingel E (2002) Inorg Chem 41:5641-5643

28. Neves A, Lanznaster M, Bortoluzzi AJ, Peralta RA, Casellato A, Castellano EE, Herrald P, Riley MJ, Schenk G (2007) J Am Chem Soc 129:7486-7487

29. Batista SC, Neves A, Bortoluzzi AJ, Vencato I, Peralta RA, Szpoganicz B, Aires VVE, Terenzi H, Severino PC (2003) Inorg Chem Commun 6:1161-1165

30. Karsten P, Neves A, Bortoluzzi AJ, Strahle J, Maichle-Mossmer C (2002) Inorg Chem Commun 5:434-438

31. Neves A, de Brito MA, Drago V, Griesar K, Haase W (1995) Inorg Chim Acta 237:131-135

32. Campbell HD, Dionysius DA, Keough DT, Wilson BE, de Jersey J, Zerner B (1978) Biochem Biophys Res Commun 82:615-620

33. Martell AE, Montekaitis RJ (1992) Determination and use of stability constants, 2nd edn. VCD, New York

34. Spek AL (1996) HELENA: CAD-4 data reduction program. University of Utrecht

35. Spek AL (1997) PLATON: molecular geometry and plotting program. University of Utrecht

36. North AC, Phillips DC, Matthews FS (1968) Acta Crystallogr Sect A 24:351-359

37. Sheldrick GM (1997) SHELXS-97: program for the solution of crystal structures. University of Göttingen

38. Sheldrick GM (1997) SHELXL-97: program for the refinement of crystal structures. University of Göttingen, Germany 
39. Ravel B, Newville M (2005) J Synchrotron Radiat 12:537-541

40. Valizadeh M, Schenk G, Nash K, Oddie GW, Guddat LW, Hume DA, de Jersey J, Burke J, Terrence R., Hamilton S (2004) Arch Biochem Biophys 424:154-162

41. Thirumavalavan M, Akilan P, Kandaswamy M (2004) Supramol Chem 16:495-504

42. Merkx M, Averill BA (1999) J Am Chem Soc 121:6683-6689

43. Huheey JE (1983) Inorganic chemistry, 3rd edn. HarperCollins, New York

44. Segel IH (1975) Enzyme kinetics: behavior and analysis of rapid equilibrium and steady-state enzyme systems. Wiley, New York

45. Guddat LW, McAlpine AS, Hume D, Hamilton S, de Jersey J, Martin JL (1999) Structure 7:757-767

46. Merkx M, Pinkse MWH, Averill BA (1999) Biochemistry 38:9914-9925

47. Funhoff EG, Wang Y, Andersson G, Averill BA (2005) FEBS J 272:2968-2977

48. Klabunde T, Sträter N, Fröhlich R, Witzel H, Krebs B (1996) J Mol Biol 259:737-748

49. Twitchett MB, Schenk G, Aquino MAS, Yiu DTY, Lau T-C, Sykes AG (2002) Inorg Chem 41:5787-5794

50. Holman TR, Juarez-Garcia C, Hendrich MP, Que L Jr, Munck E (1990) J Am Chem Soc 112:7611-7618
51. Ghiladi M, Jensen KB, Jiang J, McKenzie CJ, Morup S, Sotofte I, Ulstrup J (1999) J Chem Soc Dalton Trans 2675-2681

52. Ghiladi M, McKenzie CJ, Meier A, Powell AK, Ulstrup J, Wocadlo S (1997) J Chem Soc Dalton Trans 4011-4018

53. O'Connor CJ (1982) Prog Inorg Chem 29:203

54. Kahn O (1993) Molecular magnetism. VCH, New York

55. Mitić N, Saleh L, Schenk G, Bollinger JM Jr, Solomon EI (2003) J Am Chem Soc 125:11200-11201

56. Mitić N, Clay MD, Saleh L, Bollinger JM Jr, Solomon EI (2007) J Am Chem Soc 129:9049-9065

57. Solomon EI, Neidig ML, Schenk G (2003) In: Lever ABP (ed) Comprehensive coordination chemistry II, vol 2. Fundamentals: physical methods, theoretical analysis, and case studies. Elsevier, Amsterdam, pp 339-349

58. Riley MJ (2005) MCDfit: aspectroscopic tool for multiple curve deconvolution and fitting. http://sourceforge.net/projects/mcdfit/

59. Anjos A, Bortoluzzi AJ, Osorio RE, Peralta RA, Friedermann GR, Mangrich AS, Neves A (2005) Inorg Chem Commun 8:249-253

60. Lambert E, Chabut B, Chardon-Noblat S, Deronzier A, Chottard G, Bousseksou A, Tuchagues J-P, Laugier J, Bardet M, Latour J-M (1997) J Am Chem Soc 119:9424-9437

61. Wilkins RG (1990) Kinetics and mechanisms of reactions of transition metal complexes, 2nd edn. Wiley-VCH, Weinheim 